\title{
Fluorine partitioning between humite-group minerals and aqueous fluids: implications for volatile storage in the upper mantle
}

\author{
Lewis Hughes $^{1}\left[\right.$. $\cdot$ Alison Pawley ${ }^{1}$
}

Received: 27 March 2019 / Accepted: 13 August 2019 / Published online: 29 August 2019

(c) The Author(s) 2019

\begin{abstract}
Phase equilibrium experiments were performed in the $\mathrm{MgO}-\mathrm{SiO}_{2}-\mathrm{H}_{2} \mathrm{O}$ system, along with fluorine (MSH $+\mathrm{F}$ ), at conditions between $800-1000{ }^{\circ} \mathrm{C}$ and $2.0-2.5 \mathrm{GPa}$ to constrain the solubility of fluorine in humite-group minerals and to determine fluorine partitioning between humite-group minerals and aqueous fluid. Fluorine solubility in humite-group minerals ranges between $\sim 1$ and $11 \mathrm{wt} \% \mathrm{~F}$ and is dependent on the salinity of the fluid $(\sim 0.2-3.5 \mathrm{wt} \% \mathrm{~F})$, indicating that humitegroup minerals have exceedingly high saturation limits for $\mathrm{F}$ and that a full solid solution between $\mathrm{F}^{-}$and $\mathrm{OH}^{-}$is possible within the crystal structure. Raman spectroscopy reveals the preferential ordering of F, promoting the formation of a stable $\mathrm{OH}-\mathrm{F}$ bond. Mineral-fluid partition coefficients are always greater than unity, with average coefficients of $D_{\mathrm{F}}^{\text {clinohumite/fluid }}=3$, $D_{\mathrm{F}}^{\text {humite/fluid }}=2, D_{\mathrm{F}}^{\text {chondrodite/fluid }}=4$, and $D_{\mathrm{F}}^{\text {norbergite/fluid }}=4$. Partition coefficients are independent of pressure or temperature, but decrease with increasing fluid salinity. Fluorine is, therefore, highly soluble and compatible within this group of ultramafic mantle minerals. High solubility and mineral-fluid partition coefficients, together with wide stability fields in pressure and temperature space, demonstrate that humite-group minerals are potential storage sites for $\mathrm{F}$, and by extension $\mathrm{H}_{2} \mathrm{O}$, during subduction. Upon the breakdown of less stable hydrous and/or fluorine-rich phases during lower grades of subduction zone metamorphism, fluorine may redistribute into phases such as humite-group minerals and be transported beyond the volcanic arc and to the upper mantle.
\end{abstract}

Keywords Fluorine $\cdot$ Humite-group minerals $\cdot$ Partitioning $\cdot$ Subduction $\cdot$ Volatiles $\cdot$ Aqueous fluid

\section{Introduction}

Owing to increasing ionic radii from $\mathrm{F}$ to $\mathrm{I}$, halogen elements display a range from mildly incompatible $(\mathrm{F})$ to highly incompatible (I) behaviour within silicate minerals. This incompatible nature, coupled with their volatile behaviour, implies that halogen elements will preferentially enter silicate melts and aqueous fluids during geological processes such as melting, degassing, and dehydration reactions. Bureau et al. (2010), Dalou et al. (2012) and Bureau

Communicated by Timothy L. Grove.

Electronic supplementary material The online version of this article (https://doi.org/10.1007/s00410-019-1614-2) contains supplementary material, which is available to authorized users.

Lewis Hughes

lewis.hughes@manchester.ac.uk

1 Department of Earth and Environmental Sciences, University of Manchester, Manchester M13 9PL, UK et al. (2016) have shown experimentally that halogens show strong partitioning into silicate melts and fluid phases at conditions typical of the upper mantle. The incompatible nature of halogen elements suggests that they should not be fractionated from one another during these processes, and therefore, they make for ideal tracers of volatile transport between major geological reservoirs (Schilling et al. 1980; Ito et al. 1983; Jambon et al. 1995).

Numerous studies have been carried out to date, both experimentally and on the analysis of natural samples, to quantify the halogen content in major geological reservoirs and to constrain halogen solubility in and partitioning between melts, fluids, and major mantle minerals (e.g., Bernini et al. 2013; Hughes et al. 2018; Kendrick et al. 2018). These types of studies aim to better understand halogen and volatile mobility during subduction through constraining halogen fluxes in vs. fluxes out. The behaviour of $\mathrm{F}$ does not follow the heavier halogens, and it is argued to remain bound within the descending slab throughout subduction, as opposed to recycled via arc volcanism (e.g., 


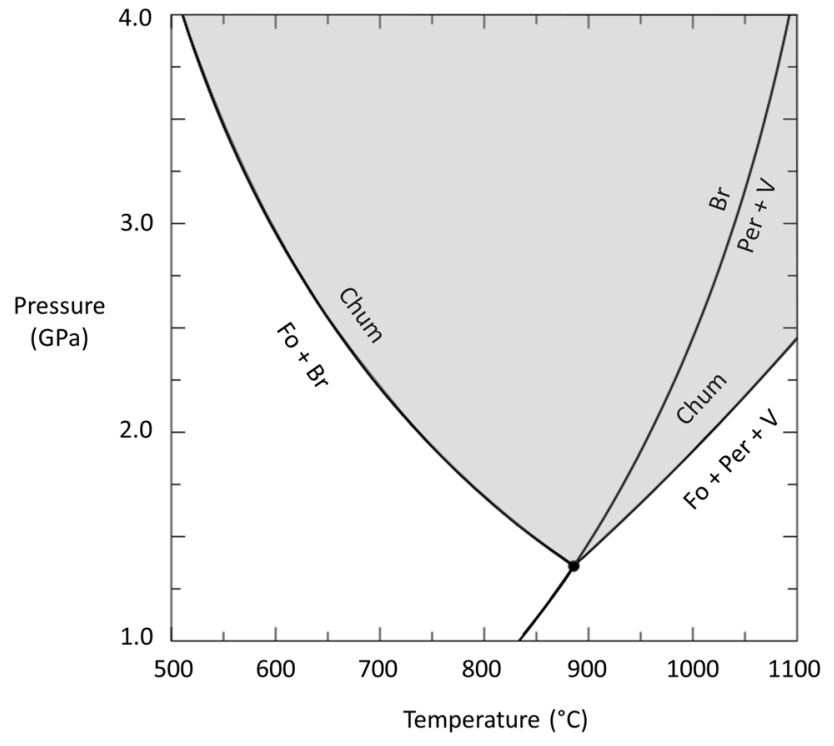

Fig. 1 Petrogenetic grid showing the expansion of the thermal stability of clinohumite with increasing pressure. Created using Perple_X (Connolly, 2009). (Br brucite, Chum clinohumite, Fo forsterite, Per periclase, $V$ vapour)

Straub and Layne 2003). The quantity of fluorine that can be transported beyond the volcanic arc, and in which minerals it can be effectively hosted during subduction, however, is not well established. Hydrous minerals such as amphibole, mica, and serpentine are postulated to be important carriers of halogen elements in subduction zones, and although these minerals are stable within the descending slab (Schmidt and Poli 2014), they eventually break down at $200 \mathrm{~km}$ or less, depending on the geotherm of the slab. This suggests that other minerals may play a more important role in the transport of $\mathrm{F}$ to the deeper mantle, beyond the stability of amphibole and serpentine. Humite-group minerals (HGM) — clinohumite, humite, chondrodite, and norbergite-are one such set of minerals.

HGM have a structure that consists of alternating layers of olivine and brucite and have the general formula $n \mathrm{M}_{2} \mathrm{SiO}_{4} \mathrm{M}(\mathrm{OH}, \mathrm{F})_{2}$, where $\mathrm{M}$ is $\mathrm{Mg}, \mathrm{Fe}^{2+}$, or $\mathrm{Mn}$, and $n=1$, 2, 3, 4 for norbergite, chondrodite, humite, and clinohumite, respectively. They are common accessory phases in hydrated ultramafic material (Engi and Lindsley 1980; Trommsdorff and Evans 1980; Evans and Trommsdorff 1983) and, importantly, exhibit wide stability fields in pressure-temperature space (Fig. 1). Their stability fields may also be expanded through the incorporation of small quantities of F (Ulmer and Trommsdorff 1999; Stalder and Ulmer 2001), allowing HGM to crystallise at shallow depths of subduction and remain stable down to transition zone conditions (Grützner et al. 2017). Few other hydrous silicate minerals show such ranges in pressure and temperature space. This suggests that HGM could be important in the storage and delivery of F,

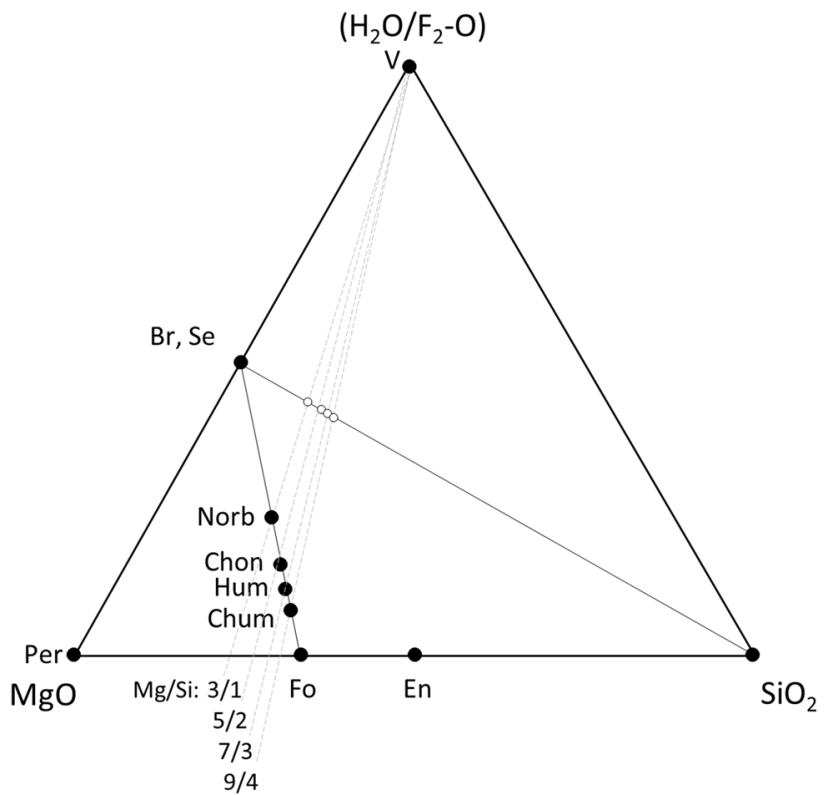

Fig. $\left.2 \mathrm{MgO}-\mathrm{SiO}_{2}-\mathrm{H}_{2} \mathrm{O} / \mathrm{F}_{2}-\mathrm{O}\right)$ ternary diagram showing the compositions of phases and starting mixtures used in this study (filled circles phases, open circles starting mixtures). The $\mathrm{Mg} / \mathrm{Si}$ ratios of the respective $\mathrm{HGM}$ are also shown. $\mathrm{H}_{2} \mathrm{O} / \mathrm{F}$ ratios of the starting mixtures are shown in Table 1. ( $\mathrm{Br}$ brucite, Chon chondrodite, Chum clinohumite, En enstatite, Fo forsterite, Hum humite, Norb norbergite, Per periclase, $S e$ Sellaite, $V$ vapour)

$\mathrm{H}_{2} \mathrm{O}$, and other volatile elements to the deeper mantle. However, HGM will only form in the appropriate bulk composition. The average mantle composition lies on the $\mathrm{SiO}_{2}$ side of the forsterite- $\mathrm{H}_{2} \mathrm{O}$ tie line, between forsterite and enstatite (Fig. 2). Since HGM lie along the forsterite-brucite tie line, they will not be stable in normal mantle compositions. Mantle compositions, however, are not expected to be homogeneous, especially at tectonic regions such as subduction zones, and occurrences of HGM in natural samples worldwide are common. Therefore, $\mathrm{Mg}$-rich/Si-poor domains within the mantle are undoubtedly present, and will allow the formation and existence of HGM as common accessory minerals in ultramafic material.

Little experimental work has been carried out to date on $\mathrm{F}$ partitioning between HGM and aqueous fluids at conditions relevant to subduction zones. Experimental studies that have been carried out have reported varying results, with Bernini et al. (2013), suggesting that F generally prefers to enter the fluid phase over HGM, while Wu and Koga (2013) suggest that $\mathrm{F}$ has a strong preference for HGM over the fluid phase. The two respective studies were conducted at low (Wu and Koga 2013) and high (Bernini et al. 2013) fluid salinities, which may explain the discrepancy. Therefore, to address the differences, this study presents new experimental results on the solubility of F in HGM and partition coefficients for F 
Table 1 Starting materials used and reagent ratios, experimental conditions, and experimental run products in synthesis experiments

\begin{tabular}{|c|c|c|c|c|c|c|c|c|}
\hline $\begin{array}{l}\text { Run } \\
\text { (starting } \\
\text { mixture) }\end{array}$ & $\begin{array}{l}\text { Starting material proportions } \\
\text { (wt } \%)\end{array}$ & $\mathrm{Mg} / \mathrm{Si}$ ratio & $\mathrm{H}_{2} \mathrm{O} / \mathrm{F}$ ratio & $\begin{array}{l}\text { wt } \% \mathrm{~F} \text { in } \\
\text { starting } \\
\text { mixture }\end{array}$ & $\mathrm{T}\left({ }^{\circ} \mathrm{C}\right)$ & $\mathrm{P}(\mathrm{GPa})$ & Time (h) & $\begin{array}{l}\text { Run products identified and } \\
\text { modal abundance of each } \\
\text { phase (wt } \% \text { ) }\end{array}$ \\
\hline F1 (1) & $\begin{array}{l}\mathrm{Mg}(\mathrm{OH})_{2}(67.8),+\mathrm{SiO}_{2} \\
(31.4)+\mathrm{MgF}_{2}(0.8)\end{array}$ & 2.25 & 44.5 & 0.50 & 900 & 2.0 & 10 & $\begin{array}{l}\text { Clinohumite }(54.2)+\text { forsterite } \\
(25.5)+\text { fluid }_{(\mathrm{aq})}(20.3)\end{array}$ \\
\hline F2 (1) & $\begin{array}{l}\mathrm{Mg}(\mathrm{OH})_{2}(67.8),+\mathrm{SiO}_{2} \\
(31.4)+\mathrm{MgF}_{2}(0.8)\end{array}$ & 2.25 & 44.5 & 0.50 & 1000 & 2.5 & 24 & $\begin{array}{l}\text { Clinohumite }(50.7)+\text { forsterite } \\
(28.8)+\text { fluid }_{(\mathrm{aq})}(20.5)\end{array}$ \\
\hline F3 (2) & $\begin{array}{c}\mathrm{Mg}(\mathrm{OH})_{2}(66.2),+\mathrm{SiO}_{2} \\
\quad(31.4)+\mathrm{MgF}_{2}(2.4)\end{array}$ & 2.25 & 14.5 & 1.49 & 800 & 2.0 & 40 & $\begin{array}{l}\text { Clinohumite }(57.3)+\text { chon- } \\
\text { drodite }(4.8)+\text { forsterite } \\
(18.6)+\text { fluid }_{(\mathrm{aq})}(19.3)\end{array}$ \\
\hline F4 (2) & $\begin{array}{l}\mathrm{Mg}(\mathrm{OH})_{2}(66.2),+\mathrm{SiO}_{2} \\
(31.4)+\mathrm{MgF}_{2}(2.4)\end{array}$ & 2.25 & 14.5 & 1.49 & 900 & 2.0 & 36 & $\begin{array}{l}\text { Clinohumite }(62.0)+\text { forsterite } \\
(18.5)+\text { fluid }_{(\mathrm{aq})}(19.5)\end{array}$ \\
\hline F6 (2) & $\begin{array}{l}\mathrm{Mg}(\mathrm{OH})_{2}(66.2),+\mathrm{SiO}_{2} \\
(31.4)+\mathrm{MgF}_{2}(2.4)\end{array}$ & 2.25 & 14.5 & 1.49 & 1000 & 2.5 & 24 & $\begin{array}{l}\text { Clinohumite }(59.0)+\text { forsterite } \\
(20.7)+\text { fluid }_{(\mathrm{aq})}(20.3)\end{array}$ \\
\hline F7 (2) & $\begin{array}{l}\mathrm{Mg}(\mathrm{OH})_{2}(66.2),+\mathrm{SiO}_{2} \\
(31.4)+\mathrm{MgF}_{2}(2.4)\end{array}$ & 2.25 & 14.5 & 1.49 & 800 & 2.0 & 40 & $\begin{array}{l}\text { Clinohumite }(52.0)+\text { chon- } \\
\text { drodite }(3.2)+\text { forsterite } \\
(24.8)+\text { fluid }_{(\mathrm{aq})}(20.0)\end{array}$ \\
\hline F8 (2) & $\begin{array}{l}\mathrm{Mg}(\mathrm{OH})_{2}(66.2),+\mathrm{SiO}_{2} \\
(31.4)+\mathrm{MgF}_{2}(2.4)\end{array}$ & 2.25 & 14.5 & 1.49 & 900 & 2.0 & 36 & $\begin{array}{l}\text { Clinohumite }(61.4)+\text { forsterite } \\
(18.4)+\text { fluid }_{(\mathrm{aq})}(20.2)\end{array}$ \\
\hline F9 (3) & $\begin{array}{l}\mathrm{Mg}(\mathrm{OH})_{2}(64.6),+\mathrm{SiO}_{2} \\
(31.3)+\mathrm{MgF}_{2}(4.1)\end{array}$ & 2.25 & 8.5 & 2.48 & 900 & 2.0 & 16 & $\begin{array}{l}\text { Clinohumite }(75.9)+\text { enstatite } \\
(2.3)+\text { fluid }_{(\mathrm{aq})}(21.8)\end{array}$ \\
\hline F11 (3) & $\begin{array}{l}\mathrm{Mg}(\mathrm{OH})_{2}(64.6),+\mathrm{SiO}_{2} \\
(31.3)+\mathrm{MgF}_{2}(4.1)\end{array}$ & 2.25 & 8.5 & 2.48 & 1000 & 2.5 & 24 & $\begin{array}{l}\text { Clinohumite }(76.0)+\text { forsterite } \\
(4.0)+\text { fluid }_{(\mathrm{aq})}(20.0)\end{array}$ \\
\hline F12 (3) & $\begin{array}{l}\mathrm{Mg}(\mathrm{OH})_{2}(64.6),+\mathrm{SiO}_{2} \\
(31.3)+\mathrm{MgF}_{2}(4.1)\end{array}$ & 2.25 & 8.5 & 2.48 & 900 & 2.0 & 24 & $\begin{array}{l}\text { Clinohumite }(75.0)+\text { forsterite } \\
(4.8)+\text { fluid }_{(\mathrm{aq})}(20.2)\end{array}$ \\
\hline F13 (5) & $\begin{array}{l}\mathrm{Mg}(\mathrm{OH})_{2}(63.4),+\mathrm{SiO}_{2} \\
(29.0)+\mathrm{MgF}_{2}(7.5)\end{array}$ & 2.50 & 4.5 & 4.60 & 900 & 2.0 & 24 & $\begin{array}{l}\text { Chondrodite }(77.3)+\text { enstatite } \\
(4.1)+\text { fluid }_{(\mathrm{aq})}(18.6)\end{array}$ \\
\hline F15 (4) & $\begin{array}{l}\mathrm{Mg}(\mathrm{OH})_{2}(64.2),+\mathrm{SiO}_{2} \\
(30.5)+\mathrm{MgF}_{2}(5.3)\end{array}$ & 2.33 & 6.5 & 3.22 & 900 & 2.0 & 24 & $\begin{array}{l}\text { Clinohumite }(48.0)+\text { humite } \\
(33.3)+\text { fluid }_{(\mathrm{aq})}(18.7)\end{array}$ \\
\hline F17 (6) & $\begin{array}{c}\mathrm{Mg}(\mathrm{OH})_{2}(61.5),+\mathrm{SiO}_{2} \\
(25.3)+\mathrm{MgF}_{2}(13.1)\end{array}$ & 3.00 & 2.5 & 8.01 & 900 & 2.0 & 24 & $\begin{array}{l}\text { Chondrodite }(61.3)+\text { norber- } \\
\text { gite }(17.2)+\text { fluid }_{(\mathrm{aq})}(21.5)\end{array}$ \\
\hline F19 (7) & $\begin{array}{c}\mathrm{Mg}(\mathrm{OH})_{2}(62.2),+\mathrm{SiO}_{2} \\
(31.3)+\mathrm{MgF}_{2}(6.5)\end{array}$ & 2.25 & 5.2 & 3.96 & 900 & 2.0 & 24 & $\begin{array}{l}\text { Clinohumite }(29.1)+\text { humite } \\
(21.7)+\text { chondrodite } \\
(27.5)+\text { enstatite } \\
(2.4)+\text { fluid }_{(\mathrm{aq})}(19.3)\end{array}$ \\
\hline
\end{tabular}

between HGM and aqueous fluids, in experiments ranging from low- to high-fluid salinities.

\section{Materials and experimental and analytical methods}

\section{Starting materials}

Experiments were conducted in the Fe-free ${\mathrm{MgO}-\mathrm{SiO}_{2}-}^{-}$ $\mathrm{H}_{2} \mathrm{O}$ system plus $\mathrm{F}(\mathrm{MSH}+\mathrm{F})$ (Fig. 2). Starting materials were reagent grade $\mathrm{Mg}(\mathrm{OH})_{2}$ and ground $\mathrm{SiO}_{2}$ glass in the molar ratio corresponding to a bulk starting material of the $\mathrm{OH}$-end member HGM, i.e., 3:1=norbergite (norb), 5:2= chondrodite (chon), 7:3= humite (hum), and 9:4= clinohumite (chum). Fluorine was added to experiments by substituting a small proportion of the $\mathrm{Mg}(\mathrm{OH})_{2}$ required for each respective HGM with $\mathrm{MgF}_{2}$ to create the following starting mixtures: (1) $8.9 \mathrm{Mg}(\mathrm{OH})_{2}: 0.1 \mathrm{MgF}_{2}$-clinohumite; (2) $8.7 \mathrm{Mg}(\mathrm{OH})_{2}: 0.3$ $\mathrm{MgF}_{2}$-clinohumite; (3) $8.5 \mathrm{Mg}(\mathrm{OH})_{2}: 0.5 \mathrm{MgF}_{2}$-clinohumite; (4) $6.5 \mathrm{Mg}(\mathrm{OH})_{2}: 0.5 \mathrm{MgF}_{2}$-humite; (5) $4.5 \mathrm{Mg}(\mathrm{OH})_{2}: 0.5$ $\mathrm{MgF}_{2}$-chondrodite; (6) $2.5 \mathrm{Mg}(\mathrm{OH})_{2}: 0.5 \mathrm{MgF}_{2}$-norbergite; and (7) $8.2 \mathrm{Mg}(\mathrm{OH})_{2}: 0.8 \mathrm{MgF}_{2}$-clinohumite. Their compositions are shown in Table 1 . This method of adding halogens ensured that the correct molar $\mathrm{Mg} / \mathrm{Si}$ ratio for the respective HGM was maintained, minimising the chance for any excess phase(s) to form that could affect the activity of $\mathrm{H}_{2} \mathrm{O}$ in the experimental run and the subsequent derived partition coefficients. All starting mixtures were more $\mathrm{H}_{2} \mathrm{O}$ rich than the respective HGM. However, there are no stable phases on the $\mathrm{H}_{2} \mathrm{O}$ side of the brucite-forsterite tie line at the synthesis conditions (Fig. 2), so this excess $\mathrm{H}_{2} \mathrm{O}$ does not pose a problem (e.g., Pawley 2000). The excess $\mathrm{H}_{2} \mathrm{O}$ will, in fact, have the beneficial effect of enhancing both the rate of reaction and the crystallinity of the run product. All 
reagents were fired to a minimum of $200{ }^{\circ} \mathrm{C}$ for at least $4 \mathrm{~h}$ before use to remove any adsorbed $\mathrm{H}_{2} \mathrm{O}$. They were then carefully weighed out and ground in an agate mortar under ethanol, for 40-60 min, to allow for thorough mixing into a homogeneous starting material.

\section{Experimental apparatus}

Starting materials were placed in annealed Pt capsules of $2 \mathrm{~mm}$ diameter and $7 \mathrm{~mm}$ length, which were then welded shut using a TIG welder. As experimental runs used solid starting materials for both $\mathrm{H}_{2} \mathrm{O}$ and halogens, the risk of volatile loss during welding was negligible. However, the weighing of all capsules both before and after welding was performed to confirm that no volatile loss occurred prior to commencing the experiments. All experiments were performed using an end-loaded Boyd and England-type piston cylinder apparatus (Boyd and England 1960). The cylindrical pressure assembly consisted (from outside to inside) of lead foil wrapped around an $\mathrm{NaCl}$ cell, with a graphite furnace of $6 \mathrm{~mm}$ diameter and inner pieces comprising crushable alumina rods and sleeve. The platinum capsules were then placed in one of two orientations, depending on experiment type. For single-capsule experiments, the capsule was placed perpendicular to the length of the alumina sleeve, at the hottest part of the furnace. For multi-capsule experiments, three capsules were placed parallel to the length of the alumina sleeve, with the mid-point of the capsules at the hottest part of the furnace. In both orientations, the capsules were separated from the $\mathrm{Pt} / \mathrm{PtRh}$ thermocouple tip by a $0.6 \mathrm{~mm}$ thick corundum disc to avoid puncturing the capsules during the run. All experiments were run using the "hot piston-out" method, where pressurisation above the target pressure was followed by heating and then the bleeding of excess pressure back to the target conditions. This method is used to minimise friction, so that a pressure correction is not necessary. Pressure was calibrated against the quartz-coesite transition data of Bohlen and Boettcher (1982), with an uncertainty of $\pm 0.05 \mathrm{GPa}$. Temperature was controlled to $\pm 1{ }^{\circ} \mathrm{C}$ using a Eurotherm temperature controller. The effect of pressure on thermocouple e.m.f. was ignored.

\section{Analysis of run products}

Run products were examined optically, by powder X-ray diffraction (XRD) and by Raman spectroscopy to identify the run products. In most experimental runs, XRD patterns showed the presence of appreciable forsterite and/or enstatite in addition to the HGM. Rietveld refinement was performed, using TOPAS software, on all run products to quantify the abundances of each solid phase, as this is important when performing mass balance calculations. Samples were then mounted in epoxy for analysis under the electron probe micro-analyser (EPMA). The F content of the coexisting fluid was calculated via mass balance. The mass balance used the bulk composition of the run, the compositions and proportions of the solid phases and the fraction of fluid (see Supplementary Material for details).

\section{Electron probe micro-analysis}

Analysis of $\mathrm{Si}, \mathrm{Mg}$, and $\mathrm{F}$ was carried out with a Cameca SX100 electron microprobe, using wavelength-dispersive spectrometry (WDS). Analysis conditions were $15 \mathrm{kV}$ accelerating voltage and $20 \mathrm{nA}$ beam current. Counting was conducted on $\mathrm{K} \alpha$ lines for all elements with $60 \mathrm{~s}$ count times to derive accurate $\mathrm{Mg} / \mathrm{Si}$ ratios for HGM identification. A PC0 (pseudo-crystal) was used for the analysis of $\mathrm{F}$ to enhance the peak resolution and counts compared to TAP crystals. As the experimental system was Fe-free, the interference from the Fe $\mathrm{L} \alpha$ peak on the $\mathrm{F} \mathrm{K} \alpha$ peak is not a concern, and pulse height analysis (PHA) settings minimised the interference of the $\mathrm{Mg} \mathrm{K} \alpha$ peak. Detection limits for $\mathrm{F}$ using this analytical setup were $\sim 500 \mathrm{ppm}$. Quantification standards used were wollastonite $(\mathrm{Si})$, periclase $(\mathrm{Mg})$, and apatite/fluorite (F) (see Supplementary Material for more details of F analysis). Stoichiometry was handled automatically by adding the appropriate number of oxygen atoms to a pre-determined list of element valences. Mineral formulae were re-calculated using $4(\mathrm{O})$ forsterite, $5(\mathrm{O})$ norbergite, $6(\mathrm{O})$ enstatite, $9(\mathrm{O})$ chondrodite, 13(O) humite, and 17(O) clinohumite. Matrix corrections used the x-phi method. Relative uncertainties $(1 \sigma)$ associated with $\mathrm{Mg}$ and Si measurements are $1 \%$. For $\mathrm{F}$ concentrations $<1 \mathrm{wt} \%, 1 \sigma$ uncertainties are $6 \%$, while for $\mathrm{F}$ concentrations $>1 \mathrm{wt} \%, 1 \sigma$ uncertainties are $3 \%$.

\section{Raman spectroscopy}

Laser Raman measurements on HGM were acquired using a Horiba XploRA PLUS spectrometer equipped with an electron-multiplying charge-coupled device (EMCCD) detector. A solid-state laser, set to a wavelength of $532 \mathrm{~nm}$, was used to excite Raman scattering. Raman spectra for HGM were obtained by averaging 5 spectra acquired with a count time of $20 \mathrm{~s}$, for shift ranges of $200-1200 \mathrm{~cm}^{-1}$ (aluminosilicate framework domain) and 3000-4000 $\mathrm{cm}^{-1}(\mathrm{OH}$-stretching domain), relative to the wavelength of the laser.

\section{Results}

Experimental run conditions and products are presented in Table 1. Experimental runs produced phase assemblages consisting of mixtures of HGM or HGM plus forsterite or enstatite, along with an aqueous fluid. The aqueous fluid was lost during retrieval of the sample, and so, 
its chemical composition and abundance were derived via mass balance calculations. HGM are generally well crystallised, 30-250 $\mu \mathrm{m}$ in size, and show sub-to-euhedral shapes (Fig. 3). No halogen-rich quenched solute phases were observed during EPMA analysis.

The quantity of forsterite in each run was dependent on the amount of $\mathrm{F}$ in the starting mixture. At $<1.5 \mathrm{wt} \% \mathrm{~F}$ in the starting mixture, experiments crystallised up to $30 \%$ forsterite coexisting with HGM (Table 1). At $>1.5 \mathrm{wt} \% \mathrm{~F}$, forsterite was present as only a few percent of the phase assemblage. The crystallisation of small quantities of enstatite with HGM occurred only in runs containing high concentrations of $\mathrm{F}$ in the starting mixture (Table 1 ). In addition, a large quantity of $\mathrm{F}$ in one of the clinohumite starting mixtures (Run F19, Table 1) promoted the crystallisation of multiple F-bearing HGM, rather than a single, F-rich clinohumite. No pressure or temperature dependence on phase assemblages or proportions was observed. In all experimental runs, HGM are solid solutions between $\mathrm{F}$ - and $\mathrm{OH}$-rich end members, and major element compositions $(\mathrm{Mg} / \mathrm{Si}$ ratios) correspond closely to the ideal stoichiometric formulae of forsterite (2:1), enstatite (1:1), clinohumite $(9: 4)$, humite $(7: 3)$, chondrodite $(5: 2)$, and norbergite (3:1).

The fluorine content in forsterite and enstatite is below the EPMA detection limit of this study ( $500 \mathrm{ppm})$ and, therefore, has a negligible effect on the mass balance of $\mathrm{F}$ and is not considered in calculations. Fluorine concentrations in HGM, in contrast, are always at weight percent levels. Fluorine concentrations in HGM vary as follows (Table 2): clinohumite $(0.84-3.65 \mathrm{wt} \% \mathrm{~F}$; molar $\left.\mathrm{F} /(\mathrm{F}+\mathrm{OH})=\mathrm{X}_{\mathrm{F}}=0.15-0.64\right)$, humite $(3.94-4.01 \mathrm{wt} \%$ $\left.\mathrm{F} ; \mathrm{X}_{\mathrm{F}}=0.49-0.51\right)$, chondrodite $(3.69-8.62 \mathrm{wt} \% \mathrm{~F}$; $\left.\mathrm{X}_{\mathrm{F}}=0.35-0.81\right)$, and norbergite $\left(11.13 \mathrm{wt} \% \mathrm{~F} ; \mathrm{X}_{\mathrm{F}}=0.62\right)$. Calculated $\mathrm{F}$ concentrations in the coexisting aqueous fluids are always lower than the F content of HGM (Table 2). After the first two experiments, with both repeat and new starting mixtures, universal indicator paper showed that upon piercing of the experimental charge, the aqueous fluid had a neutral $\mathrm{pH}$ (green). A neutral $\mathrm{pH}$ indicates that the coexisting fluid contained little $\mathrm{F}$, which is consistent with mass balance calculations. Careful weighing before and after opening capsules revealed that the quantity of fluid released was consistent with the expected residual fluid amount based on the bulk $\mathrm{H}_{2} \mathrm{O}$ content of the starting mixture. Therefore, diffusive water loss from the $\mathrm{Pt}$ capsule during runs is considered negligible.

Figure 4 shows how the solubility of $\mathrm{F}$ within clinohumite and chondrodite increases with fluid salinity. It can be seen that the F concentration in clinohumite initially increases linearly with fluid salinity, but there is a curvature to the trend at higher fluid salinities, suggesting that $\mathrm{F}$ contents are approaching saturation. The data for chondrodite are less well constrained than for clinohumite, with the highest salinity data point lying well below the trend of the other data. The roughly linear increase in $\mathrm{F}$ concentration in clinohumite and chondrodite with fluid salinities up to around $2 \mathrm{wt} \% \mathrm{~F}$ indicates that they can be reliably described using partition coefficients, as calculated in the following section.

Fluorine partition coefficients between HGM and aqueous fluid $-D_{\mathrm{F}}^{\text {hgm/fl }}$-were calculated from the F concentrations and fluid salinities in Table 2. Values from all experimental runs are higher than unity (Table 3 ). $D_{\mathrm{F}}^{\text {chum/fl }}$ ranges from 1.1 to 4.9 , with an average of $3 ; D_{\mathrm{F}}^{\text {hum/fl }}$ ranges from 1.2 to 2.5 , with an average of $2 ; D_{\mathrm{F}}^{\text {chon/fl }}$ ranges from 1.4 to 7.3 , with an average of $4 ; D_{\mathrm{F}}^{\text {norb/f }}$ is 4.4 . The coexistence of multiple HGM in some experimental runs allows for the calculation of $\mathrm{F}-\mathrm{OH}$ exchange coefficients between HGM. Table 3 shows that fluorine-hydroxyl exchange coefficients: $D_{\mathrm{F} / \mathrm{hH}}^{\mathrm{hgm} / \mathrm{hgm}}=\left(\frac{F}{(F+O H)}\right) \mathrm{hgm} /\left(\frac{F}{(F+O H)}\right)$ hgm are close to 1 and, therefore, indicate negligible fractionation of fluorine between $\mathrm{HGM}$ at conditions of $800-1000{ }^{\circ} \mathrm{C}$ and 2.0-2.5 GPa. Figure 5 shows that $\mathrm{F}$ partition coefficients decrease from $\sim 5$ to $\sim 1$ for clinohumite and $\sim 7$ to $\sim 1$ for chondrodite with increasing fluid salinity.

Figures 6 and 7 show Raman spectra for HGM with variable $\mathrm{F}$ content. Figure 6 shows that multiple spectra for the same HGM are similar within the aluminosilicate framework domain. All HGM share a similarity in their spectra at the low and high ends of the aluminosilicate framework domain, with three peaks observed between $\sim 550$ and $610 \mathrm{~cm}^{-1}$ and two peaks observed between 930 and $970 \mathrm{~cm}^{-1}$. Clinohumite (Fig. 6a) additionally shows three Raman shift peaks at 830,840 , and $860 \mathrm{~cm}^{-1}$. Chondrodite (Fig. 6b) shows two Raman shift peaks at 845 and $865 \mathrm{~cm}^{-1}$, with the peak at $845 \mathrm{~cm}^{-1}$ almost obscuring the peak at $865 \mathrm{~cm}^{-1}$. The Raman spectrum of humite (Fig. 6c) is similar to chondrodite, with peaks at 840 and $862 \mathrm{~cm}^{-1}$; however, the two peaks are similar in intensity, unlike those of chondrodite. Norbergite (Fig. 6d) has the simplest spectrum of the HGM, with a single Raman shift peak at $850 \mathrm{~cm}^{-1}$.

Figure 7a-c shows how the peaks in the $\mathrm{OH}$-stretching region change with increasing $\mathrm{F} / \mathrm{OH}$ ratio in clinohumite. Figure 7a shows that $\mathrm{OH}-$ clinohumite has two peaks, with the peak at $3525 \mathrm{~cm}^{-1}$ being slightly more intense than the peak at $3565 \mathrm{~cm}^{-1}$. However, with increasing $\mathrm{F} / \mathrm{OH}$ ratio (Fig. $7 b, c$ ), the peak at $3525 \mathrm{~cm}^{-1}$ loses intensity, relative to the peak at $3565 \mathrm{~cm}^{-1}$, until the $\mathrm{OH}$-stretching region signal is lost in F-clinohumite. Figure 7d-f shows a similar pattern in other, F-rich HGM, where chondrodite, humite, and norbergite show a weak Raman shift peak at $3525 \mathrm{~cm}^{-1}$ relative to the peak at $3565 \mathrm{~cm}^{-1}$. 

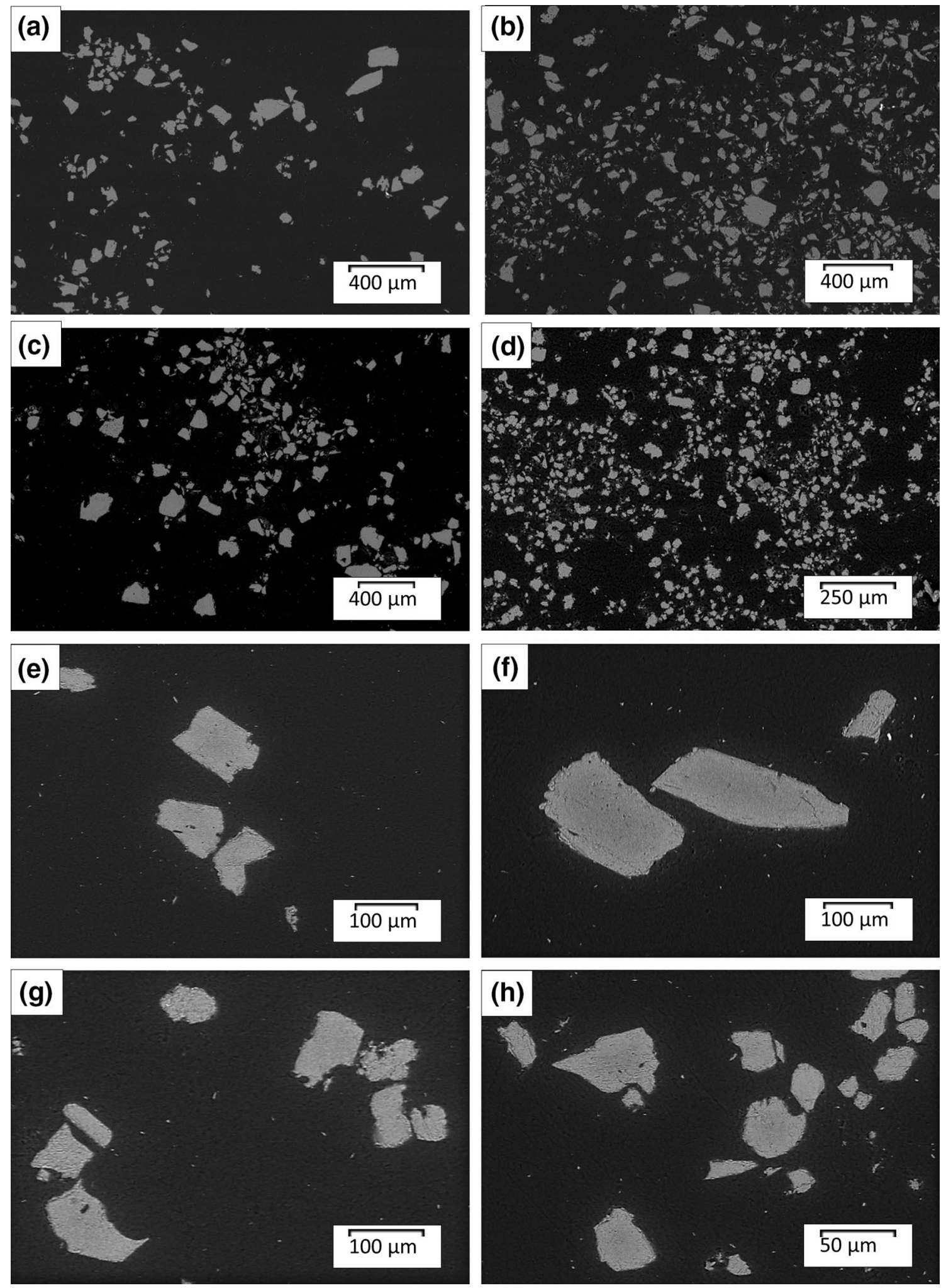

Fig. 3 Backscattered electron images of experimental run products. a Large-field view of run F4. b Large-field view of run F13. c Largefield view of run F15. d Large-field view of run F17. e Clinohumite

(run F4). f Chondrodite (run F13). g Clinohumite/humite (run F15). h Chondrodite/norbergite (run F17) 
Table 2 Fluorine concentrations (wt\%) in HGM and aqueous fluid

\begin{tabular}{|c|c|c|c|c|c|c|c|c|c|}
\hline $\begin{array}{l}\text { Run } \\
\text { (starting } \\
\text { mixture) }\end{array}$ & $\begin{array}{l}\text { Clinohumite } \\
\text { (wt\%) }\end{array}$ & $\begin{array}{l}\text { Clino- } \\
\text { humite } \\
\left(\mathrm{X}_{\mathrm{F}}\right)\end{array}$ & Humite (wt $\%$ ) & Humite $\left(\mathrm{X}_{\mathrm{F}}\right)$ & $\begin{array}{l}\text { Chondrodite } \\
(\mathrm{wt} \%)\end{array}$ & $\begin{array}{l}\text { Chon- } \\
\text { drodite } \\
\left(\mathrm{X}_{\mathrm{F}}\right)\end{array}$ & $\begin{array}{l}\text { Norbergite } \\
(\mathrm{wt} \%)\end{array}$ & $\begin{array}{l}\text { Norbergite } \\
\left(\mathrm{X}_{\mathrm{F}}\right)\end{array}$ & $\begin{array}{l}\text { Fluid salinity } \\
(\mathrm{wt} \%)\end{array}$ \\
\hline F1 (1) & $0.84 \pm 0.05$ & 0.15 & - & & - & & - & & $0.18 \pm 0.15$ \\
\hline $\mathrm{F} 2(1)$ & $0.90 \pm 0.06$ & 0.16 & - & & - & & - & & $0.18 \pm 0.16$ \\
\hline F3 (2) & $2.11 \pm 0.04$ & 0.38 & - & & $3.69 \pm 0.04$ & 0.35 & - & & $0.50 \pm 0.22$ \\
\hline F4 (2) & $2.18 \pm 0.04$ & 0.38 & - & & - & & - & & $0.67 \pm 0.33$ \\
\hline F6 (2) & $2.28 \pm 0.09$ & 0.40 & - & & - & & - & & $0.61 \pm 0.26$ \\
\hline F7 (2) & $2.32 \pm 0.04$ & 0.41 & - & & $3.96 \pm 0.04$ & 0.38 & - & & $0.70 \pm 0.25$ \\
\hline F8 (2) & $2.15 \pm 0.04$ & 0.38 & - & & - & & - & & $0.74 \pm 0.24$ \\
\hline F9 (3) & $2.67 \pm 0.11$ & 0.46 & - & & - & & - & & $1.76 \pm 0.38$ \\
\hline F11 (3) & $2.84 \pm 0.12$ & 0.49 & - & & - & & - & & $1.48 \pm 0.43$ \\
\hline F12 (3) & $2.82 \pm 0.11$ & 0.49 & - & & - & & - & & $1.65 \pm 0.39$ \\
\hline F13 (5) & - & & - & & $5.65 \pm 0.19$ & 0.53 & - & & $1.30 \pm 0.83$ \\
\hline F15 (4) & $3.34 \pm 0.13$ & 0.58 & $3.94 \pm 0.13$ & 0.49 & - & & - & & $1.60 \pm 0.71$ \\
\hline F17 (6) & - & & - & & $8.62 \pm 0.16$ & 0.81 & $11.13 \pm 0.33$ & 0.62 & $2.59 \pm 1.42$ \\
\hline F19 (7) & $3.65 \pm 0.13$ & 0.64 & $4.01 \pm 0.14$ & 0.51 & $4.65 \pm 0.16$ & 0.42 & - & & $3.42 \pm 0.69$ \\
\hline
\end{tabular}

Fluid salinity was calculated by mass balance (see Supplementary Material)

\section{Discussion}

\section{Phase relations}

The presence of forsterite or enstatite in the majority of our experiments, even though they used starting materials with $\mathrm{MgO} / \mathrm{SiO}_{2}$ ratios targeted to synthesise specific HGM, is consistent with the high F contents of the HGM. This can be seen in Fig. 8, which shows the compositions of clinohumite, starting mixture, and fluid for three typical runs: F1, F4, and F12. For each run, the clinohumite-fluid tie line does not pass through the starting mixture, but is instead displaced to a higher value of $\mathrm{F}$, resulting in the starting mixture lying in a three-phase triangle. Figure 8 also suggests that there may be some dissolution of an Mg-rich, F-poor component during the runs, since the phase proportions determined by mass balance (as shown in Fig. 8) contain slightly more forsterite than those obtained via XRD. The partial dissolution of $\mathrm{MgO}$ as well as $\mathrm{SiO}_{2}$ in the fluid must be expected at the pressures and temperatures investigated in our experiments, but the total amount of dissolution cannot be quantified. No quench phase was detected optically, by Raman spectroscopy or by XRD.

In our experiments, $\mathrm{F}$ concentrations in HGM increase with fluid salinity (Fig. 4), and increased F content in the nominal fluid promotes multiple HGM, as opposed to a single F-rich HGM. This appears to reflect the increasing stability and occurrence of F-rich HGM with increasing quantities of $\mathrm{F}$ in the system, as shown by the phase equilibrium studies of Duffy and Greenwood (1979), Rice (1980a,b) and Weiss (1997). These studies showed that phase relations involving HGM are complex, comprising multiple divariant and univariant reactions, with OH-HGM being metastable at relatively low pressure, relative to forsterite + brucite. With increasing $\mathrm{F}$ in the system, clinohumite, followed by chondrodite and then norbergite, become stable. Following the crystallisation of F-rich HGM, their eventual breakdown results in a series of continuous reactions over the range of hundreds of degrees Celsius, in which the crystallisation of further F-rich HGM occurs, i.e., clinohumite $\rightarrow$ chondrodite + forsterite or clinohumite $\rightarrow$ norbergite + forsterite.

The observed run products in this study show that, at an appropriate $\mathrm{Mg} / \mathrm{Si}$ ratio, F-bearing clinohumite, humite, chondrodite, and norbergite are all stable at temperatures and pressures relevant to subduction zones. However, the crystallisation of substantial quantities of chondrodite and clinohumite in runs F15 and F17 (Table 1), which had starting mixtures targeted to crystallise $100 \%$ humite and norbergite, suggests that the former two, monoclinic HGM, have wider stability fields than the latter two, orthorhombic HGM. This suggestion is consistent with the limited occurrences of humite and norbergite in natural samples worldwide, and humite and norbergite may in fact be metastable at the conditions of this study.

The coexistence of HGM with enstatite in F-rich runs (Table 1) is interesting, as Stalder and Ulmer (2001) showed that this assemblage is stable only above $4 \mathrm{GPa}$ at the temperatures investigated in this study, reacting at lower pressures to forsterite $+\mathrm{H}_{2} \mathrm{O}$. The experiments of Stalder and Ulmer (2001) were conducted with pure water, and it is, therefore, likely that in the presence of $\mathrm{F}$, this reaction is shifted down in pressure, allowing HGM to coexist with 
Fig. 4 Halogen concentration in mineral phases vs. fluid salinity. Data have been separated into runs resulting in three- and fourphase assemblages. a Fluorine concentration in clinohumite vs. fluid salinity and $\mathbf{b}$ fluorine concentration in chondrodite vs. fluid salinity. Squares threephase assemblages, circles four-phase assemblages
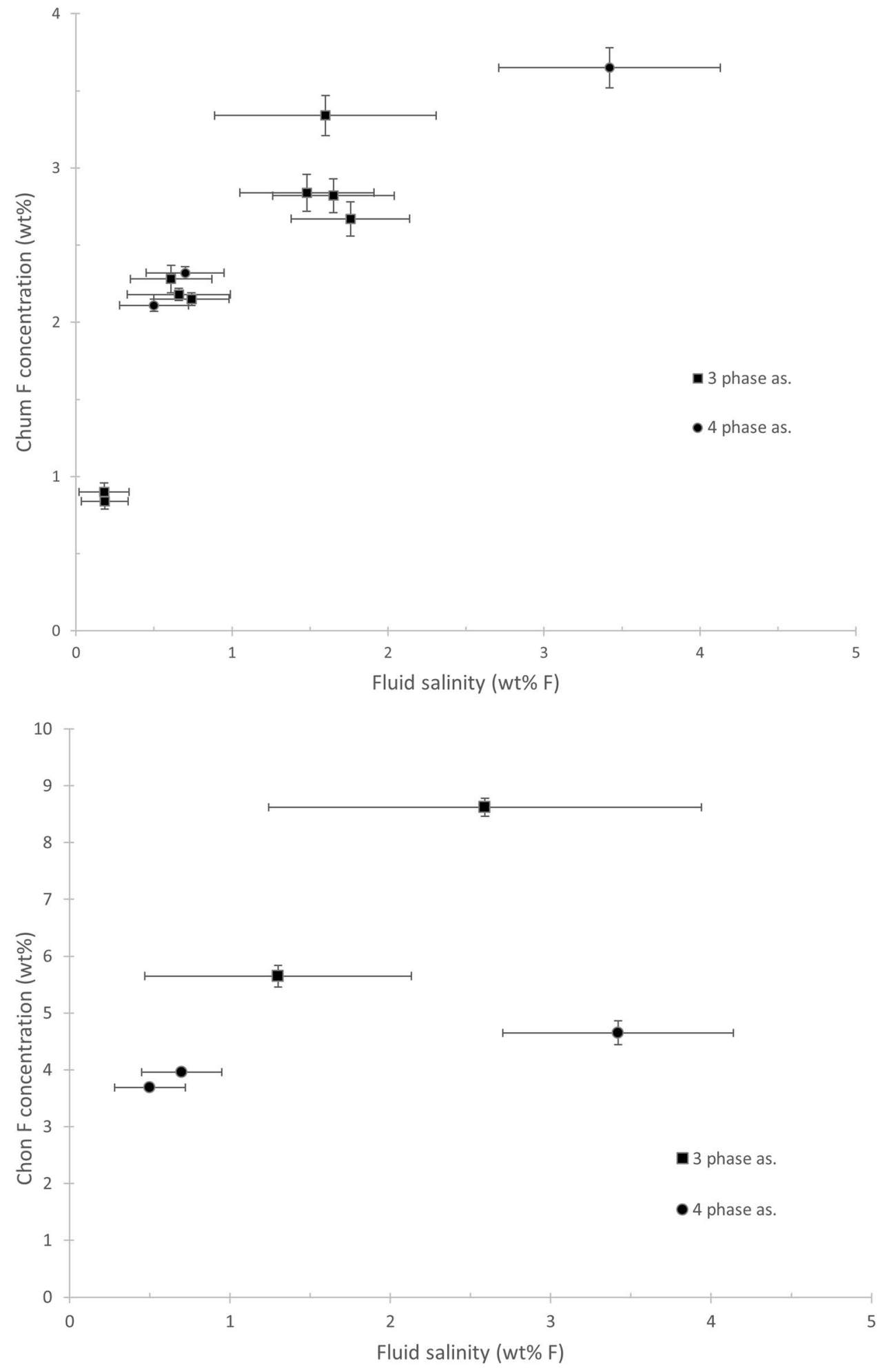

enstatite at much lower pressures than in a pure water system. Previous studies have shown that, in the presence of $\mathrm{F}$, F-bearing HGM may crystallise at considerably lower pressures than their $\mathrm{OH}$-endmember counterparts. For example, Van Valkenburg (1961) synthesised F-endmember humites at atmospheric pressure. The synthesis of F-endmember clinohumite was also successfully reproduced in this study by furnace heating at $1200{ }^{\circ} \mathrm{C}$ at atmospheric pressure. XRD of the run product (see Supplementary Material) showed that the F-endmember clinohumite coexisted with enstatite. Bernini et al. (2013) also observed the coexistence of enstatite with several HGM at high-fluid salinities and 
Table 3 Partition coefficients between HGM and aqueous fluid

\begin{tabular}{llllll}
\hline $\begin{array}{l}\text { Run (starting } \\
\text { mixture) }\end{array}$ & $D_{\mathrm{F}}^{\text {chum/fl }}$ & $D_{\mathrm{F}}^{\text {hum/fl }}$ & $D_{\mathrm{F}}^{\text {chon/fl }}$ & $D_{\mathrm{F}}^{\text {norb/fl }}$ & $D_{\mathrm{F} / \mathrm{HH} / \mathrm{HGM}}^{\text {H }}$ \\
\hline F1 (1) & $4.6(2.5-28)$ & - & - & - & - \\
F2 (1) & $4.9(2.7-45)$ & - & - & - & - \\
F3 (2) & $4.2(2.9-7.5)$ & - & $7.3(5.1-13)$ & - & 1.1 (chum/chon) \\
F4 (2) & $3.3(2.2-6.4)$ & - & - & - & - \\
F6 (2) & $3.8(2.6-6.5)$ & - & - & - & - \\
F7 (2) & $3.3(2.4-5.2)$ & - & $5.7(4.2-8.8)$ & - & 1.1 (chum/chon) \\
F8 (2) & $2.9(2.2-4.3)$ & - & - & - & - \\
F9 (3) & $1.5(1.3-1.9)$ & - & - & - & - \\
F11 (3) & $1.9(1.5-2.7)$ & - & - & - & - \\
F12 (3) & $1.7(1.4-2.3)$ & - & - & - & - \\
F13 (5) & - & - & $4.3(2.7-12)$ & - & 1.2 (chum/hum) \\
F15 (4) & $2.1(1.4-3.8)$ & $2.5(1.7-4.4)$ & - & - & 1.3 (chon/norb) \\
F17 (6) & - & - & $3.3(2.2-7.4)$ & $4.4(2.8-10)$ & 1.3 (chum/hum) \\
F19 (7) & $1.1(0.9-1.3)$ & $1.2(1.0-1.5)$ & $1.4(1.1-1.7)$ & - & 1.5 (chum/chon) \\
& & & & & 1.2 (hum/chon) \\
\hline
\end{tabular}

Values in parentheses indicate ranges in partition coefficients based on the uncertainties associated with fluid salinity

$f l$ aqueous fluid, chum clinohumite, hum humite, chon chondrodite, norb norbergite, HGM humite-group mineral pressure and temperature conditions similar to this study. These results and observations demonstrate that the presence of $\mathrm{F}$ has a significant effect on the phase relations of the MSH system in $P-T$ space.

Some of the runs in this study contain assemblages with four phases (Table 1). Given that the $\mathrm{MSH}+\mathrm{F}$ system is a simple four component system with no free oxygen phase nor redox reaction, this represents the maximum number of phases that can exist in equilibrium in a divariant field of $P-T$ space without violating the phase rule. Runs resulting in three-phase assemblages will contain HGM that have F contents dictated by fluid composition. For runs resulting in four-phase assemblages, on the other hand, we cannot be certain that the F content of HGM is dictated solely by partitioning. Therefore, it is prudent to consider whether the F content of HGM in runs with four-phase assemblages is a function of $\mathrm{P}$ and $\mathrm{T}$ and dictated by the reactions, rather than strictly by fluid composition. In Figs. 5 and 6, data are separated into three- and four-phase assemblages. It would be expected that, if the F content of HGM was dictated by different factors based on three- vs. four-phase assemblages, data would lie on separate trends. Figures 5 and 6 show that data for both three- and four-phase assemblages lie on the same trend and, therefore, indicate that the distribution of F within HGM is the same, regardless of whether there are three or four equilibrium phases in an assemblage.

Figure 4 shows that the saturation limit for $F$ within the structure of clinohumite is being approached in experiments at high-fluid salinity. Therefore, it may be more appropriate to assess the incorporation of F within HGM in terms of distribution coefficients $(\mathrm{Kd})$ of the exchange reaction between $\mathrm{F}-\mathrm{OH}$ in the mineral with $\mathrm{F}-\mathrm{OH}$ in the fluid, rather than partitioning. However, to present the data as distribution coefficients requires the calculation of the $\mathrm{OH}^{-}$concentration of the coexisting fluid at the conditions of the run, which is beyond the scope of this study. As we see a linear relationship between fluid salinity and F concentration in the HGM at the fluid salinities expected of natural systems (Fig. 4), it is justifiable to assess the incorporation of F in HGM as if it is a partition coefficient.

\section{Incorporation mechanisms and the ordering of fluorine in humite-group minerals}

The ionic radius of fluorine is similar to that of the hydroxyl ion ( 1.33 $\AA$ and $1.40 \AA$, respectively; Shannon 1976), with both having equal charge. This allows for efficient substitution of the $\mathrm{OH}^{-}$ion by $\mathrm{F}^{-}$into the structure of HGM, such that a solid solution exists between $\mathrm{OH}$ - and F- endmembers (e.g., Van Valkenburg 1961; Duffy and Greenwood, 1979; Rice 1980a, b). Berry and James (2001) and Griffin et al. (2010) have shown that HGM contain two distinct, disordered proton sites (H1 and H2-Fig. 9a, b) within the crystal structure, with occupancy of around $50 \%$ at each site. The question arises, therefore, of how and where the substitution of $\mathrm{OH}^{-}$by $\mathrm{F}^{-}$is accomplished within HGM, and how $\mathrm{F}$ substitution interacts with the $\mathrm{H} 1$ and $\mathrm{H} 2$ proton sites. 
Fig. 5 Partition coefficients for F between HGM vs. fluid salinity. a $D_{\mathrm{F}}^{\text {Chum/fl }}$ vs. fluid salinity and $\mathbf{b} D_{\mathrm{F}}^{\text {Chon/fl }}$ vs. fluid salinity. Squares three-phase assemblages, circles four-phase assemblages. Also shown are the data of Bernini et al. (2013) and $\mathrm{Wu}$ and Koga (2013)
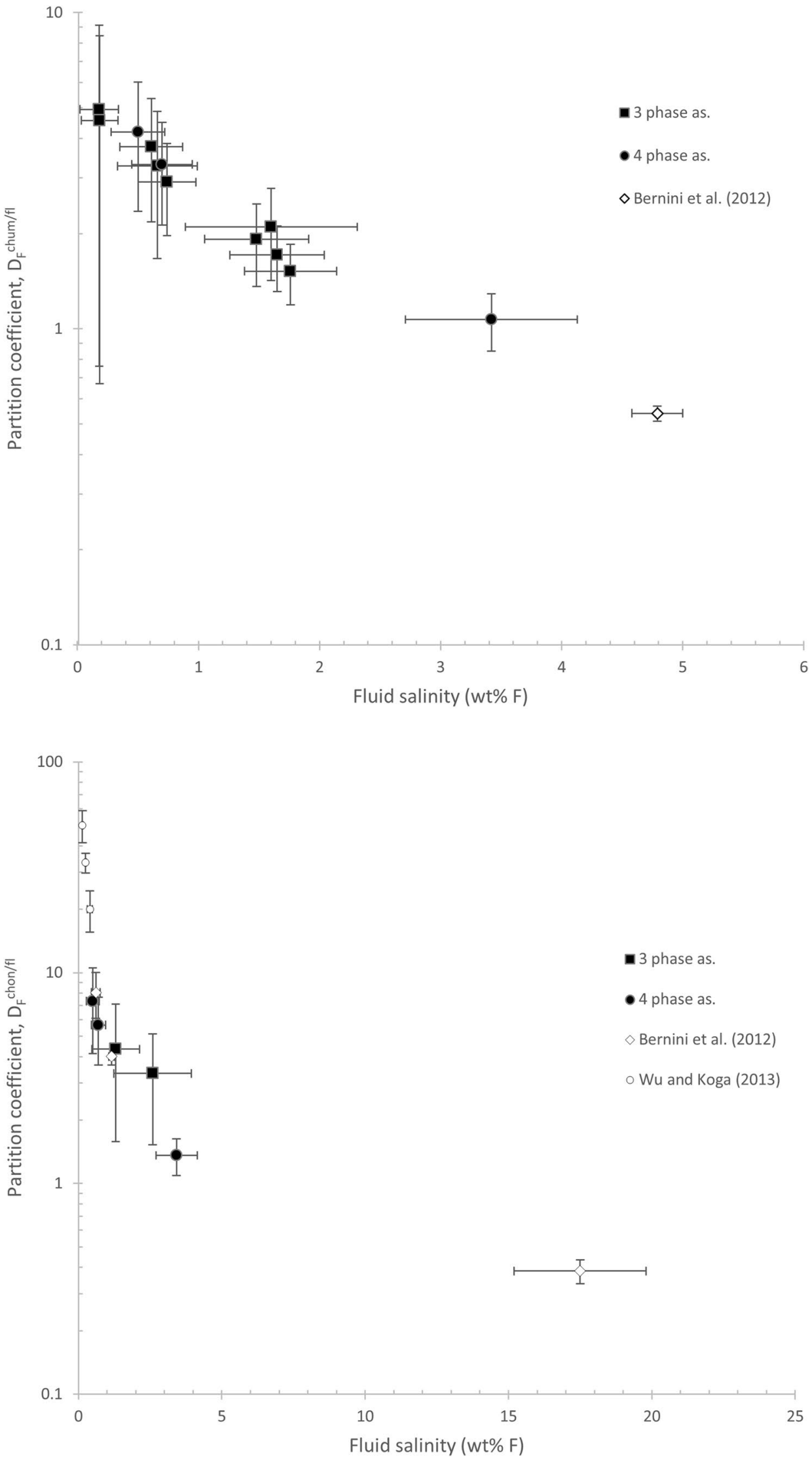

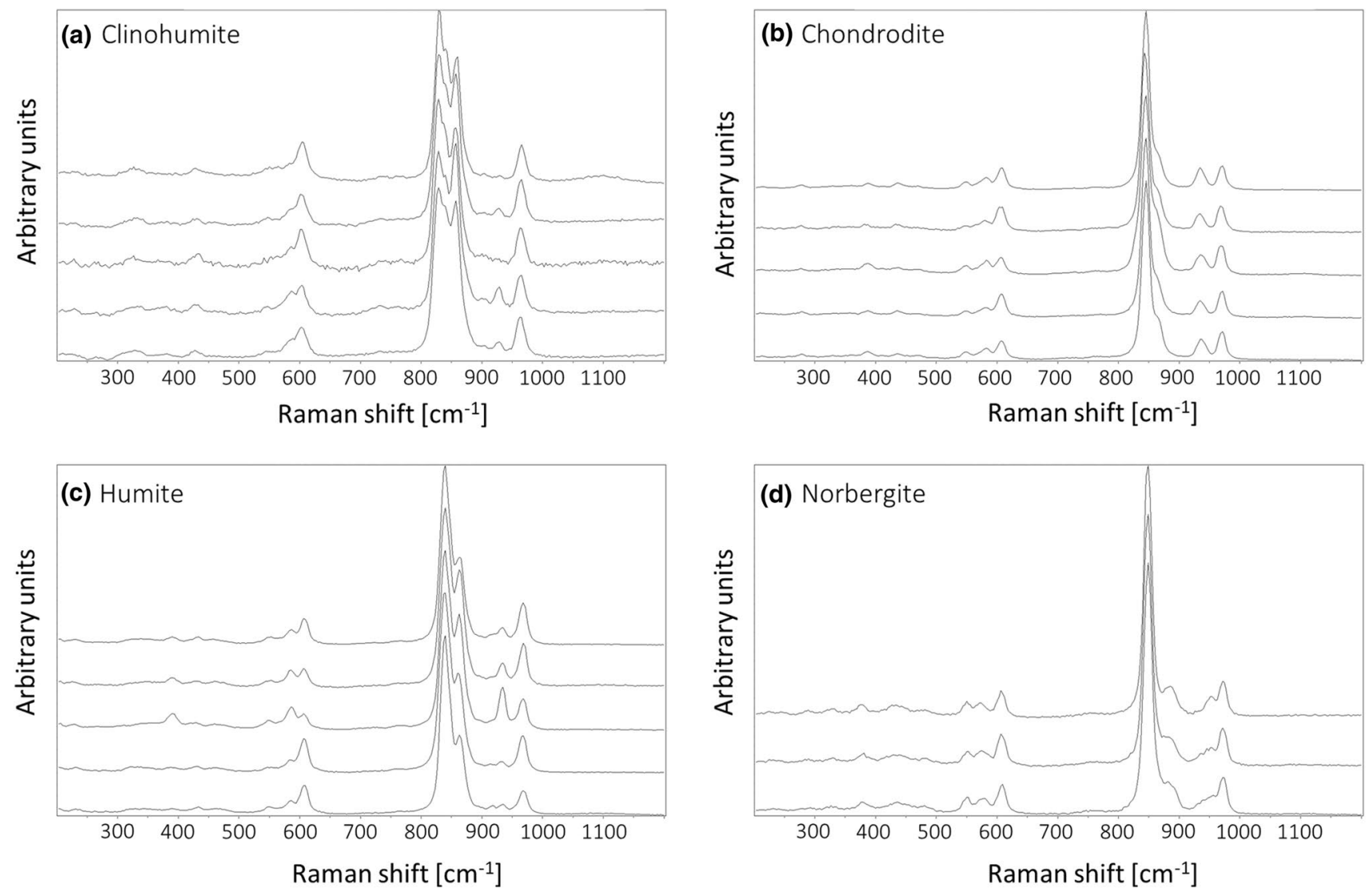

Fig. 6 Raman spectra of the aluminosilicate domain for: $\mathbf{a}$ clinohumite, $\mathbf{b}$ chondrodite, $\mathbf{c}$ humite, and $\mathbf{d}$ norbergite

The presence of two peaks in the $\mathrm{OH}$-stretching region of HGM (Fig. 7) corresponds to two, crystallographically distinct $\mathrm{OH}$ bonds within the crystal structure. This is consistent with the presence of two unique proton sites. The two bonds are described by Frost et al. (2007) as "long" and "short" bonds, with the two peaks attributed to the bonds' respective strengths relating to the distance between the brucite and adjacent olivine layer. The evolution of Raman spectra with increasing fluorine here (Fig. 7), therefore, may provide insight into where and how $\mathrm{F}$ is ordered into the structure of $\mathrm{HGM}$, with respect to the $\mathrm{H} 1$ and $\mathrm{H} 2$ sites. The loss in intensity of the $3525 \mathrm{~cm}^{-1}$ peak, relative to the $3565 \mathrm{~cm}^{-1}$ peak (Fig. 7) with increasing F content, suggests that one of the two $\mathrm{OH}$ bonds is preferentially replaced with increasing fluorine incorporation, and that upon reaching fluorine content equivalent to an $\mathrm{X}_{\mathrm{F}}$ of 0.5 and, thus, $1 \mathrm{~F}$ p.f.u., the ordering of $\mathrm{F}^{-}$and $\mathrm{OH}^{-}$at the $\mathrm{H}$ sites within HGM attempts to achieve the existence of a single $\mathrm{OH}$ bond within the crystal structure, as depicted schematically in Fig. 9. This suggestion is consistent with Griffin et al. (2010) who argue that with F incorporation, hydroxyl groups favour occupancy at the $\mathrm{H} 1$ site over the $\mathrm{H} 2$ site due to the formation of a stable $\mathrm{OH}-\mathrm{F}$ hydrogen bond. Figure 7 shows that upon reaching $X_{F}=0.50$ in clinohumite, humite and chondrodite and $\mathrm{X}_{\mathrm{F}}=0.60$ in norbergite, a small portion of the $3525 \mathrm{~cm}^{-1}$ peak remains. This indicates that although there appears to be preferential ordering of $\mathrm{H}$ into the $\mathrm{H} 1$ site, it is not complete, and the $\mathrm{H} 2$ site can still contain small quantities of hydrogen at $X_{F} \geq 0.50$. Therefore, the Raman shift peak at $3525 \mathrm{~cm}^{-1}$ can be assigned to the $\mathrm{H} 2$ position, and the $3565 \mathrm{~cm}^{-1}$ peak can be assigned to the $\mathrm{H} 1$ position. The Raman shift peak at $3610 \mathrm{~cm}^{-1}$ present in natural and synthetic clinohumite analysed by Ye et al. (2013) and Liu et al. (2019) was not observed in this study, neither in the $\mathrm{OH}$-clinohumite Raman spectrum nor in the F-bearing clinohumite Raman spectrum (Fig. 7). Kleppe and Jephcoat (2006) also did not observe the presence of a peak at $3610 \mathrm{~cm}^{-1}$ in their Raman analysis of $\mathrm{OH}-$ clinohumite. Lin et al. (2000) and Ye et al. (2013) showed that the intensity of the $3610 \mathrm{~cm}^{-1}$ peak is extremely weak in their synthetic, pure $\mathrm{Mg}$ and $\mathrm{Fe}$-bearing, and $\mathrm{OH}$-end member clinohumite. This suggests that the $3610 \mathrm{~cm}^{-1}$ peak likely represents only a minor fraction of the total number of $\mathrm{OH}$ bonds within the crystal structure. The peak is likely attributed to $\mathrm{H}$ in Si-vacancies in the olivine module of the HGM, as this peak is common in spectra from experiments investigating water incorporation in olivine (e.g., Berry et al. 2005; Walker et al. 2007). 

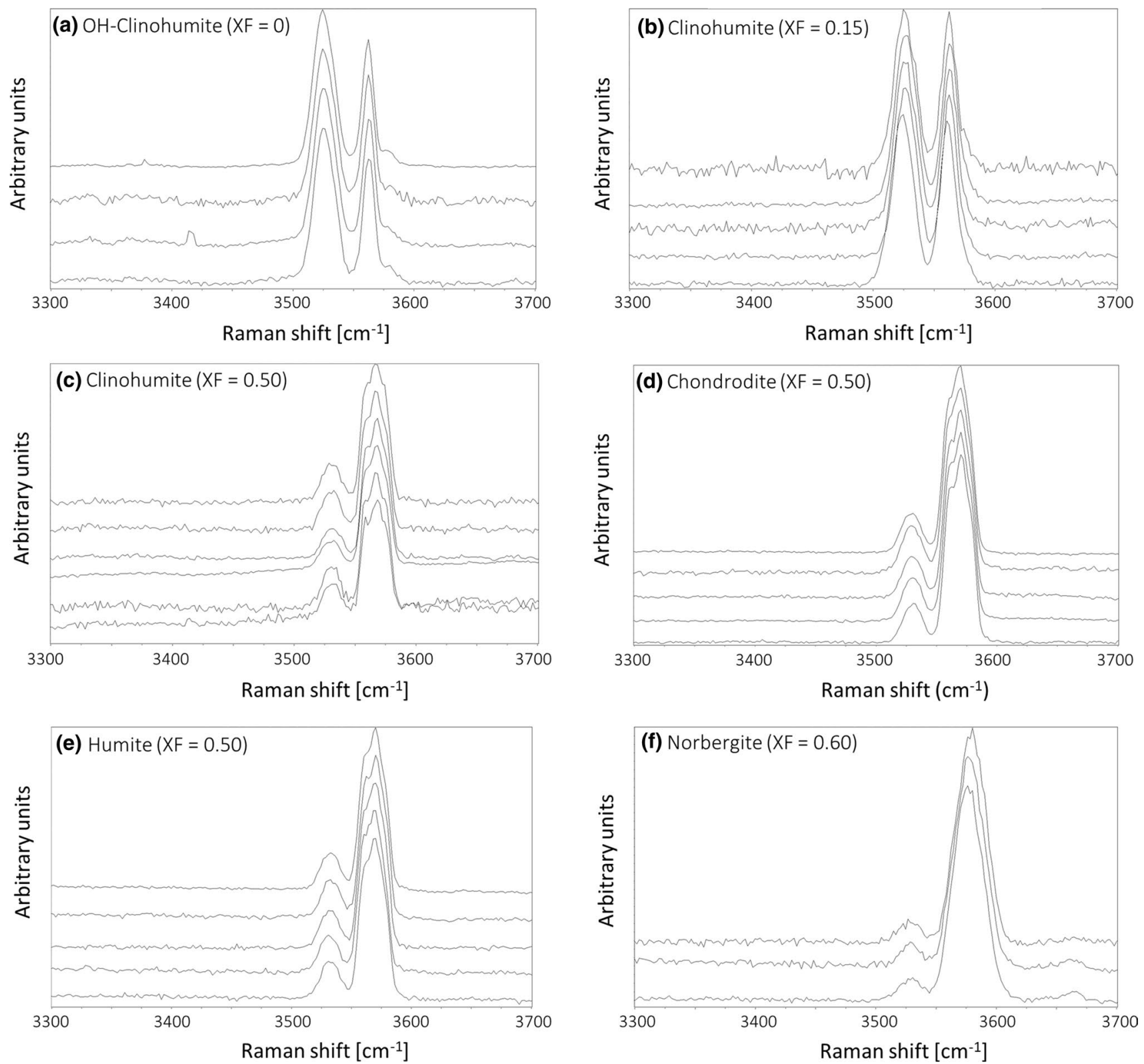

Fig. 7 Raman spectra of the $\mathrm{OH}$-stretching region of clinohumite with increasing $\mathrm{F}$ content: $\mathbf{a} \mathrm{X}_{\mathrm{F}}=0, \mathbf{b} \mathrm{X}_{\mathrm{F}}=0.15$, $\mathbf{c} \mathrm{X}_{\mathrm{F}}=0.5$, d OH-stretching region of chondrodite with $\mathrm{X}_{\mathrm{F}}=0.5$, e OH-stretching region of humite with $\mathrm{X}_{\mathrm{F}}=0.5$, and $\mathbf{f} \mathrm{OH}$-stretching region of norbergite with $\mathrm{X}_{\mathrm{F}}=0.6$

Our Raman spectra (Fig. 7) show that the intensity of the $3525 \mathrm{~cm}^{-1}$ peak in $\mathrm{HGM}$ relative to the $3565 \mathrm{~cm}^{-1}$ peak is sensitive to the $\mathrm{F} / \mathrm{OH}$ ratio of the mineral. This suggests that Raman spectra of HGM can be used to estimate their fluorine contents. The pattern of Raman spectra with increasing F content observed here is similar to FTIR results obtained by Koga et al. (2014) on a natural titanian-clinohumite, who showed that the $\mathrm{OH}$-stretching region is sensitive to the $\mathrm{F} / \mathrm{OH}$ ratio, such that the relative intensity of the peaks at $3528 \mathrm{~cm}^{-1}$ and $3565 \mathrm{~cm}^{-1}$ changes with increasing $\mathrm{F}$ content, as does the intensity of a band at $3390 \mathrm{~cm}^{-1}$. They used the relationship between the intensity of the $3390 \mathrm{~cm}^{-1}$ band and the $3565 \mathrm{~cm}^{-1}$ band to derive an equation for quantifying the F content of clinohumite. However, the band at $3390 \mathrm{~cm}^{-1}$ observed by Koga et al. (2014) was not observed in this study, and is, therefore, likely to be associated with the $\mathrm{TiH}_{2} \mathrm{Mg}_{-1}$ substitution mechanism (Engi and Lindsley 1980). Its absence in Ti-free samples means that the equation of Koga et al. (2014) is not appropriate for F-rich, Ti-poor clinohumite samples. The relationship between the intensity ratio of the $3525 \mathrm{~cm}^{-1}$ and $3565 \mathrm{~cm}^{-1}$ peaks with increasing $\mathrm{F}$ obtained in this study is shown in Fig. 10 and may be used as a more reliable approximation of the $\mathrm{F}$ content of 
Fig. 8 Diagram depicting an $\mathrm{x}-\mathrm{y}$ plot of the shaded section of the inset $\mathrm{Mg}-(\mathrm{OH})_{2}-\mathrm{F}_{2}$ ternary plot, showing the compositions of clinohumite, starting mixture and fluid from runs F1, $\mathrm{F} 4$, and F12

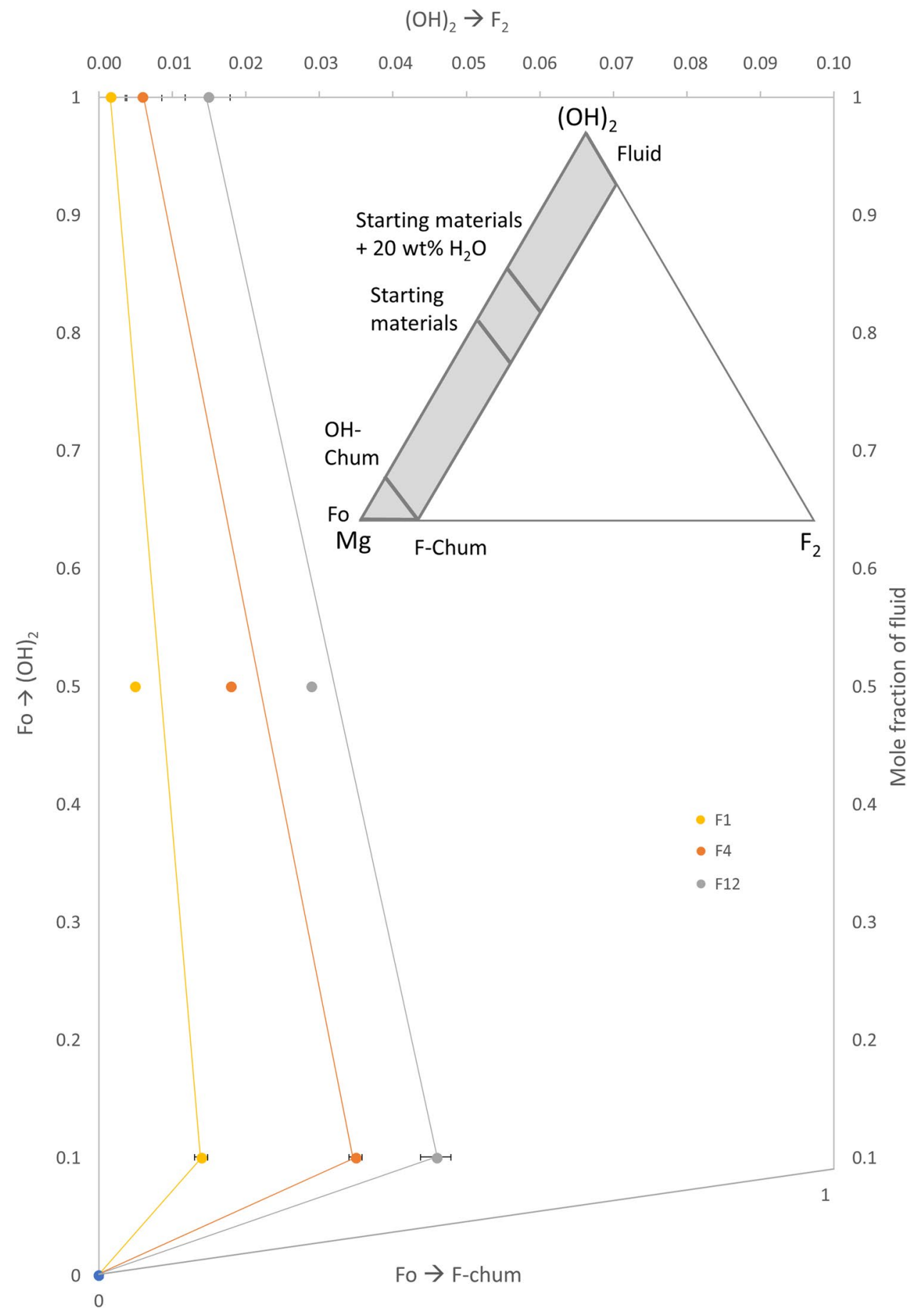

unknown, Ti-poor clinohumite. Further work on samples with moderate quantities of both $\mathrm{Ti}$ and $\mathrm{F}$ would be useful.

\section{The storage of fluorine and water within humite-group minerals during subduction}

Our experiments demonstrate that partition coefficients for fluorine between HGM and aqueous fluid are high (Table 3) and that fluorine solubility in all HGM is at the several wt \% level. Previous experimental research provided varying results with regard to the partitioning behaviour of $\mathrm{F}$ between HGM and aqueous fluids. Wu and Koga (2013) showed that norbergite and chondrodite have high $\mathrm{F}$ mineral-fluid partition coefficients, with average values of $D_{\mathrm{F}}^{\text {chon/fl }}=34$ and $D_{\mathrm{F}}^{\text {norb/fl }}=81$. In contrast, Bernini et al. (2013) showed that F showed a preference for the fluid phase over HGM, except for chondrodite, which showed variable partition coefficients from $D_{\mathrm{F}}^{\text {chon/fl }}<1$ to $D_{\mathrm{F}}^{\text {chon/fl }}>1$. These conflicting results may 
(a)

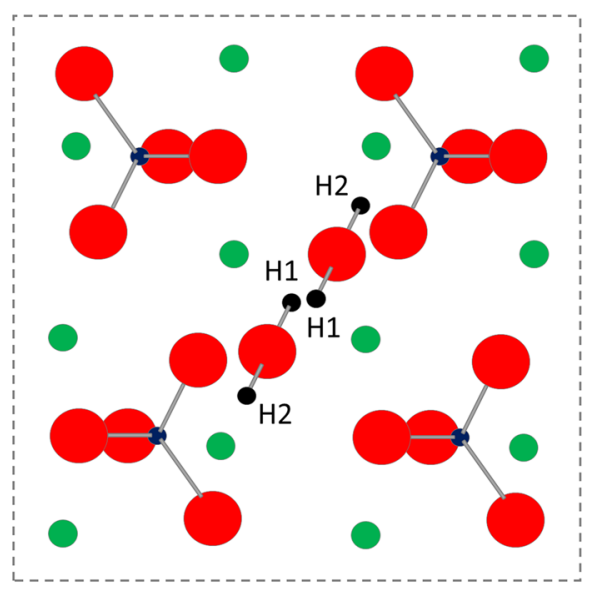

(b)

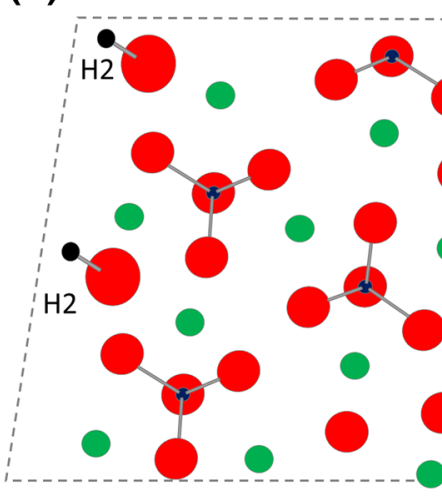

(c)

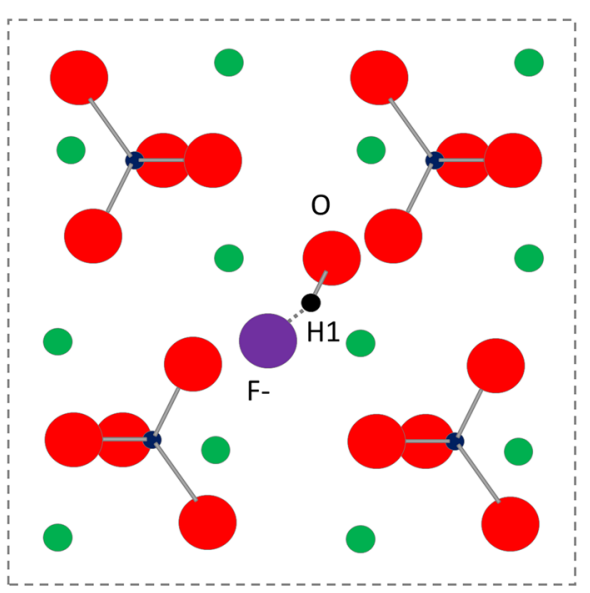

(d)
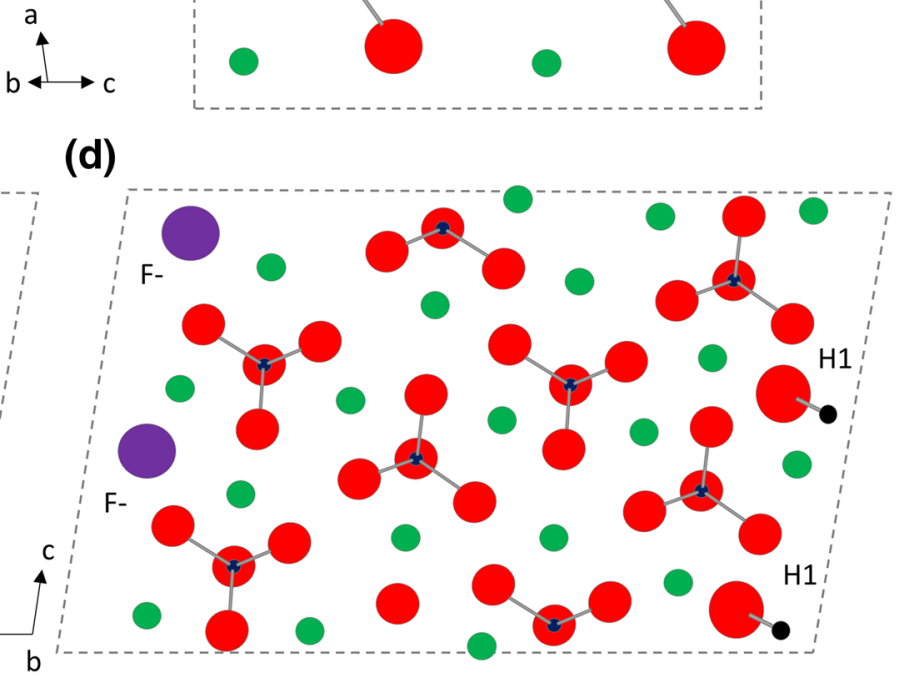

Fig. 9 Schematic views of the crystal structure of clinohumite, showing a two proton sites $\mathrm{H} 1$ and $\mathrm{H} 2$ that are associated with each $\mathrm{OH}$ group, $\mathbf{b}$ one of the possible hydroxyl group arrangements, $\mathbf{c}$ fluorine substituted for $\mathrm{OH}$, showing the creation of an $\mathrm{OH}-\mathrm{F}$ bond, d clino- humite unit cell as per $\mathbf{b}$ with $\mathrm{F}^{-}$substituted for $\mathrm{OH}^{-}$. Silicon atoms are in blue, magnesium atoms are in green, oxygen atoms are in red, fluorine atoms are in purple and hydrogen atoms are in black Adapted from Griffin et al. (2010)

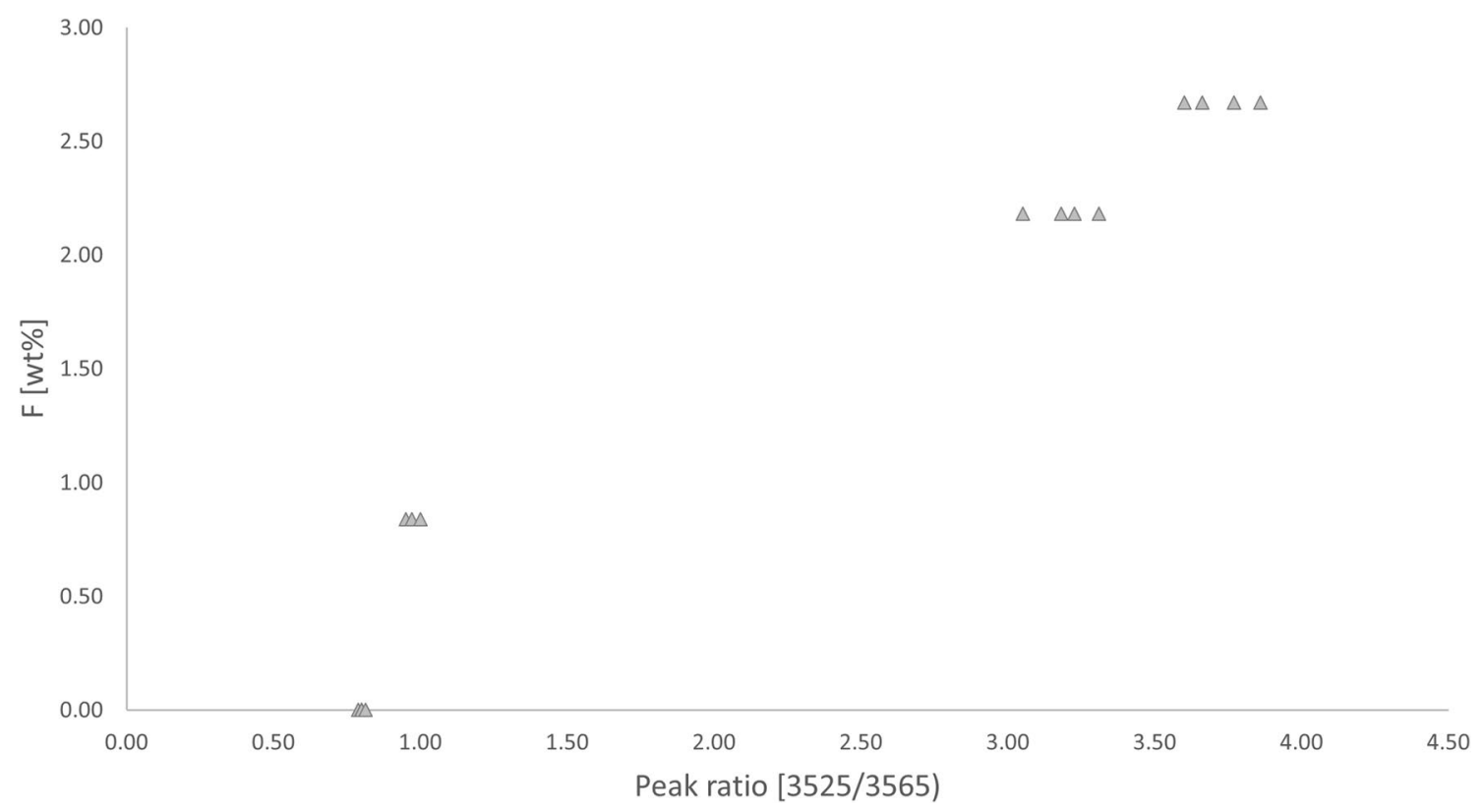

Fig. $10 \mathrm{~F}$ content (wt\%) vs. the ratio of Raman shift $3252 / 3565 \mathrm{~cm}^{-1}$ intensity in clinohumite 
be related to the high nominal fluid salinities of the experiments by Bernini et al. (2013). For example, in their experiment that showed $D_{\mathrm{F}}^{\text {chon/fl }}<1$, the nominal fluid had a salinity of $\sim 34 \mathrm{wt} \% \mathrm{~F}$, while experiments which produced $D_{\mathrm{F}}^{\text {chon/fl }}>1$ had a much lower nominal salinity $(\sim 2-4 \mathrm{wt} \% \mathrm{~F})$. The low salinity chondrodite data of Bernini et al. (2013) match the results of Wu and Koga (2013) within one order of magnitude. Therefore, it is possible that the experiments of Bernini et al. (2013) with high nominal salinity exceeded the F saturation limit of chondrodite, and other HGM, causing the partition coefficient $D_{\mathrm{F}}^{\text {chon/fl }}$ to decrease with increasing fluid salinity, and resulting in $\mathrm{F}$ appearing incompatible in other HGM. Without low fluid salinity data for other HGM in the study by Bernini et al. (2013), it is not possible to determine if they would follow the same trend, as does chondrodite. The results of this study match the results of Wu and Koga (2013) well (Fig. 5) and suggest that F displays a strong preference for HGM over aqueous fluids at conditions relevant to subduction zones. Calculated partition coefficients in this study, therefore, can be applied to natural systems to determine the fluorine content of the fluid that was in equilibrium with the HGM during crystallisation.

It was previously demonstrated that $\mathrm{OH}-\mathrm{HGM}$ are ideal candidates for storing water in the upper mantle, as they have wide ranges in stability and can remain stable to $12 \mathrm{GPa}$, but eventually break down at temperatures of $1150{ }^{\circ} \mathrm{C}$ or lower (e.g., Yamamoto and Akimoto 1977; Wunder 1998; Pawley 2000; Stalder and Ulmer 2001). A high crystallisation pressure of $2 \mathrm{GPa}$ was argued by Wunder (1998) to limit the relevance of HGM in the storage of water in the upper mantle. Pawley (2000), however, showed that the lower pressure limit of clinohumite is in fact closer to $1 \mathrm{GPa}$, and, therefore, that HGM will crystallise before significant dehydration of the subducting crust occurs. In addition, the substitution of even small amounts of $\mathrm{OH}^{-}$by $\mathrm{F}^{-}$will significantly increase HGM stability (Stalder and Ulmer 2001), in agreement with experimental data on the substitution of $\mathrm{OH}^{-}$by $\mathrm{F}^{-}$in amphiboles, micas, and other hydrates (Holloway and Ford 1975; Foley 1991; Ulmer and Trommsdorff, 1999; Harlow 2002). Weiss (1997) showed that F-clinohumite may remain stable up to $1450{ }^{\circ} \mathrm{C}$ at $3 \mathrm{GPa}$ and, as mentioned previously, Van Valkenburg (1961) synthesised F-endmember humites at atmospheric pressure. This implies that the addition of F to HGM not only increases thermal stability, but also depresses the "humite-in" reaction to much lower pressures. As $\mathrm{OH}$-endmember humites are rare in nature, it can be assumed that the majority of natural HGM will contain appreciable quantities of fluorine and/or titanium (e.g., Jones 1969; Evans and Trommsdorff 1983; Ehlers and Hoinkes 1987; Satish-Kumar and Niimi 1998), such that natural HGM will be more stable than their $\mathrm{OH}$ counterparts. Grützner et al. (2017) conducted high-pressure experiments to assess the upper stability limits of F-bearing HGM and found that F-bearing HGM are indeed much more stable than their $\mathrm{OH}$ counterparts. They showed that clinohumite with even with small quantities of $\mathrm{F}$, equivalent to $\mathrm{X}_{\mathrm{F}}=0.25$ $(\sim 1.5 \mathrm{wt} \% \mathrm{~F})$, is stable to $1400{ }^{\circ} \mathrm{C}$ at a pressure of $10 \mathrm{GPa}$. This represents an increase in thermal stability of around $400{ }^{\circ} \mathrm{C}$ over $\mathrm{OH}$-clinohumite. Furthermore, they showed that F-HGM have stability fields that extend to $>1780{ }^{\circ} \mathrm{C}$ at a pressure of $17 \mathrm{GPa}$. Their experiments show that the upper limit of stability of F-clinohumite is $\sim 200{ }^{\circ} \mathrm{C}$ higher than the temperature of the mantle transition zone, assuming a normal mantle adiabat. Their high-temperature stability, therefore, should allow F-bearing HGM to remain stable not only to great depths within the subducting slab, but also within the hydrated mantle wedge above the subducting slab. As the mantle wedge is repeatedly fluxed with volatile-rich fluids and, depending on the geotherm, hydrous melts derived from the subducting slab, liberated volatiles such as F may redistribute into HGM that crystallise in the hydrated mantle wedge, and be carried down to the deeper mantle, along with the subducting slab, via viscous coupling (Tatsumi 1989). Woodland et al. (2018) in fact showed, through experiments aiming to replicate the interaction between a subducting slab and overlying mantle wedge, that upon fluxing with F-bearing fluid derived from underlying sedimentary material, HGM crystallised within the overlying peridotite, at the contact zone between the two lithologies. Previously, HGM were argued to be limited to Mg-rich domains within the mantle (Wunder 1998), due to their formation being prohibited in normal mantle compositions (Fig. 2). Mantle compositions can, however, be expected to be inhomogeneous, especially in regions where pervasive fluid flow and mass transfer operates, i.e., subduction zone settings. It is possible that in subduction zones, hydrothermal fluids could dissolve $\mathrm{SiO}_{2}$ from some regions and precipitate it in others (Pawley 2000), resulting in $\mathrm{Mg}$-rich/Si-poor domains conducive to the formation of HGM. Woodland et al. (2018) showed that upon the interaction of volatile-bearing, slab-derived fluids with mantle peridotite of normal composition, F stabilises HGM and permits their formation, even though they are not expected in normal peridotitic compositions. The results of this study suggest that in regions of abundant fluid flow such as found at subduction zones, HGM are not as restricted as they would be in other regions of the mantle. Importantly, the coexistence of enstatite with F-rich HGM (Table 1) indicates that HGM are not restricted to bulk compositions with $\mathrm{Mg} / \mathrm{Si}$ ratios greater than forsterite. Therefore, HGM may be more volumetrically abundant within the subducting crust and mantle wedge peridotite than previously thought.

HGM may play a further role in the storage of $\mathrm{H}_{2} \mathrm{O}$ and $\mathrm{F}$ during subduction of olivine, through humite-type defects located within the olivine structure. Humite lamellae are well known and reported to form at nano-to-microscopic scale within the structure of olivine associated with prograde 
chlorite harzburgites (e.g., Wirth et al. 2001; Berry et al. 2005; Lopez Sánchez-Vizcaíno et al. 2005; Hermann et al. 2007; Risold et al. 2001; Shen et al. 2014). Given the modal abundance of olivine within the subducting layer of mantle peridotite, and its stability during subduction, potentially large quantities of $\mathrm{F}$ and $\mathrm{H}_{2} \mathrm{O}$ may be released from humite lamellae and become trapped as fluid inclusions within the structure of subducted olivine, to be subducted to and stored in the deeper mantle.

Overall, high F solubility and partition coefficients for F between HGM and aqueous fluid observed in this study reinforce the status of HGM as potentially significant candidates for the storage of $\mathrm{H}_{2} \mathrm{O}$ and $\mathrm{F}$ within the upper mantle. Due to the hydrophobic nature of $\mathrm{F}$ in hydrothermal systems, it can be expected that subduction zone-derived fluids will likely have low F contents. The increase in $D_{\mathrm{F}}^{\mathrm{HGM} / \text { fluid }}$ values with decreasing fluid salinity shown in Fig. 5, therefore, suggests that the higher partition coefficients can be considered the normal behaviour in natural systems, and serves to reinforce $\mathrm{HGM}$ as potential $\mathrm{F}$ sinks in ultramafic material during subduction. HGM may provide a more effective means of transporting $\mathrm{F}$ to, and storing it in, the deeper mantle than other accessory phases such as apatite, given that HGM can contain significantly more $\mathrm{F}$ within their crystal structure (e.g., apatite F solubility $=\sim 3.7 \mathrm{wt} \%$ maximum) and their formation is not limited by the availability of low abundance elements such as P. In addition, their wide stability fields in $P-T$ space, increased further by the incorporation of small quantities of F, allow HGM to remain stable beyond conditions where other postulated storage phases, i.e., amphibole and antigorite, break down. Upon the breakdown of these high-pressure hydrous phases, any $\mathrm{F}$ that is liberated may then redistribute into HGM through the interaction of fluid with mantle peridotite. Therefore, HGM could significantly increase the amount of $\mathrm{H}_{2} \mathrm{O}$ and $\mathrm{F}$ that is transported to the deeper mantle and should be considered in future calculations of mantle volatile content and fluxes.

\section{Conclusions}

Phase equilibrium experiments between $800-1000{ }^{\circ} \mathrm{C}$ and 2.0-2.5 GPa show that HGM have exceedingly high solubility of F, with $\mathrm{F}$ concentrations increasing with fluid salinity. Partition coefficients for $\mathrm{F}$ between mineral and fluid are consistently $>1$ in HGM, with average partition coefficients $\left(D_{\mathrm{F}}^{\mathrm{min} / \mathrm{fl}}\right)$ of 3 for clinohumite, 2 for humite, 4 for chondrodite, and 4 for norbergite, indicating that fluorine has a preference for the silicate phase. Partition coefficients are independent of temperature or pressure, but decrease with increasing fluid salinity. At the low $\mathrm{F}$ expected in fluids of natural systems, HGM show a propensity for the uptake of F. Raman spectroscopy reveals the preferential replacement of a single
$\mathrm{OH}$ bond during the incorporation of fluorine to form a stabilising $\mathrm{OH}-\mathrm{F}$ bond. Calculated partition coefficients here may be used to determine the $\mathrm{F}$ content of fluids in equilibrium with HGM in natural settings. F-bearing HGM may be able to store and transport appreciable quantities of $\mathrm{F}, \mathrm{H}_{2} \mathrm{O}$, and other volatiles to the deeper mantle both in the subducting slab and overlying mantle wedge and could significantly increase the volatile content of the mantle.

Acknowledgements This manuscript forms part of the first author's $\mathrm{PhD}$ thesis, undertaken at the University of Manchester. Financial support for this project was provided by Natural Environment Research Council grant NE/L002469/1. We thank Heath Bagshaw for help with Raman spectroscopy and Jon Fellowes for help with EPMA. We are grateful to Jörg Hermann and one anonymous reviewer for their constructive comments that helped to improve this manuscript.

Open Access This article is distributed under the terms of the Creative Commons Attribution 4.0 International License (http://creativeco mmons.org/licenses/by/4.0/), which permits unrestricted use, distribution, and reproduction in any medium, provided you give appropriate credit to the original author(s) and the source, provide a link to the Creative Commons license, and indicate if changes were made.

\section{References}

Bernini D, Wiedenbeck M, Dolejs D, Keppler H (2013) Partitioning of halogens between mantle minerals and aqueous fluids: implications for the fluid flow regime in subduction zones. Contrib Mineral Petrol 165:117-128

Berry AJ, James M (2001) Refinement of hydrogen positions in synthetic hydroxyl-clinohumite by powder neutron diffraction. Am Mineral 86:181-184

Berry AJ, Hermann J, O’Neill HSC, Foran GJ (2005) Fingerprinting the water site in mantle olivine. Geology 33:869-872

Bohlen SR, Boettcher AL (1982) The quartz $\leftrightarrows$ coesite transformation: a precise determination and the effects of other components. $\mathrm{J}$ Geophys Res 87:7073-7078

Boyd FR, England JL (1960) Apparatus for phase-equilibrium measurements at pressures up to 50 kilobars and temperatures up to $1750^{\circ} \mathrm{C}$. J Geophys Res 65:741-748

Bureau H, Foy E, Raepsaet C, Somogyi A, Munsch P, Simon G, Kubsky S (2010) Bromine cycle in subduction zones through in situ $\mathrm{Br}$ monitoring in diamond anvil cells. Geochim Cosmochim Acta 74:3839-3850

Bureau H, Auzende AL, Marocchi M, Raepsaet C, Munsch P, Testemale D, Mezouar M, Kubsky S, Carriere M, Ricolleau A, Fiquet $\mathrm{G}$ (2016) Modern and past volcanic degassing of iodine. Geochim Cosmochim Acta 173:114-125

Connolly JAD (2009) The geodynamic equation of state: what and how. Geochem Geophys 10:Q10014

Dalou C, Koga KT, Shimizu N, Boulon J, Devidal JL (2012) Experimental determination of $\mathrm{F}$ and $\mathrm{Cl}$ partitioning between lherzolite and basaltic melt. Contrib Mineral Petrol 163:591-609

Duffy CJ, Greenwood HJ (1979) Phase equilibria in the system MgO$\mathrm{MgF}_{2}-\mathrm{SiO}_{2}-\mathrm{H}_{2} \mathrm{O}$. Amer Mineral 64:1156-1173

Ehlers K, Hoinkes G (1987) Titanian chondrodite and clinohumite in marbles from the Ötztal crystalline basement. Mineral Petrol $36: 13-25$ 
Engi M, Lindsley DH (1980) Stability of titanian clinohumite: experiments and thermodynamic analysis. Contrib Mineral Petrol $72: 415-424$

Evans BW, Trommsdorff V (1983) Fluorine hydroxyl titanian clinohumite in Alpine recrystallized garnet peridotite: Compositional controls and petrologic significance: Amer J Sci 283:355-369

Foley S (1991) High-pressure stability of the fluor- and hydroxyendmembers of pargasite and K-richterite. Geochim Cosmochim Acta 55:2689-2694

Frost RL, Palmer S, Bouzaid J, Reddy J (2007) A Raman spectroscopic study of humite minerals. J Raman Spectrosc 38:68-77

Griffin J, Miller A, Berry AJ, Wimperis S, Ashbrook E (2010) Dynamics on the microsecond timescale in hydrous silicates studied by solid-state ${ }^{2} \mathrm{H}$ NMR spectroscopy. Phys Chem Chem Phys 12:2989-22998

Grützner T, Klemme S, Rohrbach A, Gervasoni F, Berndt J (2017) The role of F-clinohumite in volatile recycling processes in subduction zones. Geology 45:443-446

Harlow GE (2002) Diopside + F-rich phlogopite at high P and T: systematics, crystal chemistry and the stability of $\mathrm{KMgF} 3$, clinohumite and chondrodite. Geol Mater Res 4:1-28

Hermann J, Fitz Gerald JD, Malaspina N, Berry AJ, Scambelluri $\mathrm{M}$ (2007) $\mathrm{OH}$-bearing planar defects in olivine produced by the breakdown of Ti-rich humite minerals from Dabie Shan (China). Contrib. Mineral. Petrol. 153:417-428

Holloway JR, Ford CE (1975) Fluid-absent melting of the fluorohydroxy amphibole pargasite to 35 kilobars. Earth Planet Sci Lett 25:44-48

Hughes L, Burgess R, Chavrit D, Pawley A, Tartèse R, Droop G, Ballentine C, Lyon IC (2018) Halogen behaviour in subduction zones: eclogite facies rocks from the Western and Central Alps. Geochim Cosmochim Acta 243:1-23

Ito E, Harris DM, Anderson AT (1983) Alteration of oceanic crust and geologic cycling of chlorine and water. Geochim Cosmochim Acta 47:1613-1624

Jambon A, Déruelle B, Dreibus G, Pineau F (1995) Chlorine and bromine abundance in MORB: the contrasting behavior of the Mid- Atlantic Ridge and East Pacific Rise and implications for chlorine geodynamic cycle. Chem Geol 126:101-117

Jones NW (1969) Crystallographic nomenclature and twinning in the humite minerals. Amer Mineral 54:309-313

Kendrick M, Scambelluri M, Hermann J, Padrón-Navarta JA (2018) Halogens and noble gases in serpentinites and secondary peridotites: implications for seawater subduction and the origin of mantle neon. Geochim Cosmochim Acta 235:285-304

Kleppe AK, Jephcoat AP (2006) Raman spectroscopic studies of hydrous and nominally anhydrous deep mantle phases. In: Jacobsen SD, van der Lee S (eds) Earth's Deep Water Cycle. American Geophysical Union, Washington, D.C., pp 69-93

Koga K, Garrido CJ, Padrón-Navarta JA, López Sánchez-Vizcaíno V, Gómez-Pugnaire MT (2014) FTIR and Raman spectroscopy characterization of fluorine-bearing titanian clinohumite in antigorite serpentinite and chlorite harzburgite. Earth Planets Space 66:60

Lin CC, Liu LG, Mernagh TP, Irifune T (2000) Raman spectroscopic study of hydroxyl-clinohumite at various pressures and temperatures. Phys Chem Miner 27:320-331

Liu D, Pang Y, Ye Y, Jin Z, Smyth J, Yang Y, Zhang Z, Wang Z (2019) In-situ high-temperature vibrational spectra for synthetic and natural clinohumite: implications for dense hydrous magnesium silicates in subduction zones. Am Mineral 104:53-63

Lopez Sánchez-Vizcaíno V, Trommsdorff V, Gómez-Pugnaire M, Garrido C, Müntener O, Connolly JAD (2005) Petrology of titanian clinohumite and olivine at the high-pressure breakdown of antigorite serpentinite to chlorite harzburgite (Almirez Massif, S. Spain). Contrib Mineral Petrol 149:627-646
Pawley A (2000) Stability of clinohumite in the system $\mathrm{MgO}_{-} \mathrm{SiO}_{2-}$ $\mathrm{H}_{2} \mathrm{O}$. Contrib Mineral Petrol 138:284-291

Rice JM (1980a) Phase equilibria involving humite minerals in impure dolomitic limestones. Part I. Calculated stability of clinohumite. Contrib Mineral Petrol 71:219-235

Rice JM (1980b) Phase equilibria involving humite minerals in impure dolomitic limestones. Part II: calculated stability of chondrodite and norbergite. Contrib Mineral Petrol 75:205-223

Risold AC, Trommsdorff V, Grobety B (2001) Genesis of ilmenite rods and palisades along humite-type defects in olivine from Alpe Arami. Contrib Miner Petrol 140:619-628

Satish-Kumar M, Niimi N (1998) Fluorine-rich clinohumite from Ambasamudram marbles, southern India: mineralogical and preliminary FTIR spectroscopic characterization. Mineral Mag 62:509-519

Schilling JG, Bergeron MB, Evans R (1980) Halogens in the mantle beneath the North Atlantic. Philos Trans R Sot London Ser A 297:147-178

Schmidt MW, Poli S (2014) Devolatilization during subduction. In: Holland HD, Turekian KK (eds) Treatise on geochemistry, 2nd edn. Elsevier, Amsterdam, pp 669-701

Shannon RD (1976) Revised effective ionic radii and systematic studies of interatomic distances in halides and chalogenides. Acta Crystall A $32: 751-767$

Shen T, Hermann J, Zhang L, Padrón-Navarta J, Chen J (2014) FTIR spectroscopy of Ti-chondrodite, Ti-clinohumite, and olivine in deeply subducted serpentinites and implications for the deepwater cycle. Contrib Miner Petrol 167:992

Stalder R, Ulmer P (2001) Phase relations of a serpentine composition between 5 and $14 \mathrm{GPa}$ : significance of clinohumite and phase $\mathrm{E}$ as water carriers into the transition zone. Contrib Miner Petrol 140:670-679

Straub SM, Layne GD (2003) The systematics of chlorine, fluorine, and water in Izu arc front volcanic rocks: implications for volatile recycling in subduction zones. Geochim Cosmochim Acta 67:4179-4203

Tatsumi Y (1989) Migration of fluid phases and genesis of basalt magmas in subduction zones. J Geophys Res 94:4697-4707

Trommsdorff V, Evans BW (1980) Titanian hydroxyl-clinohumite: formation and breakdown in antigorite rocks (Malenco, Italy). Contrib Miner Petrol 72:229-242

Ulmer P, Trommsdorff V (1999) Phase relations of hydrous mantle subducting to $300 \mathrm{~km}$. Mantle Petrology: field Observations and High-Pressure Experimentation. Spec Publ Geochem Soc 6:259-281

Van Valkenburg A (1961) Synthesis of the humites $\mathrm{nMg} 2 \mathrm{SiO} 4 \cdot \mathrm{Mg}(\mathrm{F}$, $\mathrm{OH}) 2$. J Res Nat Bur Stand Sect A 65:415428

Walker AM, Hermann J, Berry AJ, O'Neill HSC (2007) Three water sites in upper mantle olivine and the role of titanium in the water weakening mechanism. J Geophys Res 112:B5211

Weiss M (1997), Clinohumites, a field and experimental study, [Ph.D thesis]. ETH Zürich, Zürich

Wirth R, Dobrzhinetskaya LF, Green HW (2001) Electron microscope study of the reaction olivine $+\mathrm{H}_{2} \mathrm{O}+\mathrm{TiO}_{2} \rightarrow$ titanian clinohumite + titanian chondrodite synthesized at $8 \mathrm{GPa}, 1300 \mathrm{~K}$. Am Mineral 86:601-610

Woodland AB, Bulatov VK, Brey GP, Girnis AV, Höfer HE, Gerdes A (2018) Subduction factory in an ampoule: experiments on sediment-peridotite interaction under temperature gradient conditions. Geochim Cosmochim Acta 223:319-349

Wu J, Koga KT (2013) Fluorine partitioning between hydrous minerals and aqueous fluid at $1 \mathrm{GPa}$ and $770-947^{\circ} \mathrm{C}$ : a New Constraint on Slab Flux. Geochim Cosmochim Acta 119:77-92

Wunder B (1998) Equilibrium experiments in the system $\mathrm{MgO}$ $\mathrm{SiO}_{2}-\mathrm{H}_{2} \mathrm{O}$ (MSH): stability fields of clinohumite-OH 
$\left[\mathrm{Mg}_{9} \mathrm{Si}_{4} \mathrm{O}_{16}(\mathrm{OH})^{2}\right]$, chondrodite- $\mathrm{OH}\left[\mathrm{Mg}_{5} \mathrm{Si}_{2} \mathrm{O}_{8}(\mathrm{OH})^{2}\right]$ and phase A $\left(\mathrm{Mg}_{7} \mathrm{Si}_{2} \mathrm{O}_{8}(\mathrm{OH})^{6}\right)$. Contrib Miner Petrol 16:111-120

Yamamoto K, Akimoto SI (1977) The system $\mathrm{MgO}-\mathrm{SiO}_{2}-\mathrm{H}_{2} \mathrm{O}$ at high pressures and temperatures; stability field for hydroxylchondrodite, hydroxyl-clinohumite and $10 \AA$-phase. Amer J Sci 277:288-312

Ye Y, Smyth J, Jacobsen S, Goujon C (2013) Crystal chemistry, thermal expansion and Raman spectra of hydroxyl-clinohumite: implications for water in Earth's interior. Contrib Miner Petrol 165:563-574

Publisher's Note Springer Nature remains neutral with regard to jurisdictional claims in published maps and institutional affiliations. 